\title{
QUADRO GERAL DOS DIREITOS DA PERSONALIDADE
}

\author{
GENERAL OVERVIEW OF THE PERSONALITY RIGHTS
}

Antonio Carlos Morato*

\begin{abstract}
Resumo:
Este artigo pretende oferecer uma visão global dos direitos da personalidade, desde a possibilidade de sua aplicação às pessoas jurídicas, passando pela superposição do estudo de seu objeto por outros ramos do Direito, assim como por dados históricos, classificação, análise jurisprudencial, doutrinária e legislativa dos pontos centrais que envolvem tais direitos.
\end{abstract}

Palavras-chave: Direitos da personalidade. Pessoas físicas. Pessoas jurídicas. Personalidade. Direito geral de personalidade. Teorias. Classificação.

\begin{abstract}
:
This paper aims to provide an overview about personality rights, from the possibility of its application to legal entities, through superposition of its object of study by other branches of law, as well as historical data, classification, analysis jurisprudential, doctrinal legislative and core issues which involve such rights.
\end{abstract}

Keywords: Personality Rights. Individual Entities. Legal Entities. Personality. General Right Of Personality. Theories. Classification..

1. Os direitos da personalidade e o âmbito da teoria

Em inspirada síntese acerca do impacto que teve o estudo dos direitos da personalidade para a concepção jurídica tradicional - exclusivamente patrimonialista - Francisco Cavalcanti Pontes de Miranda afirmou que "com a teoria dos direitos de personalidade começou, para o mundo, nova manhã do Direito" e, de fato, um longo caminho foi trilhado até que os direitos da personalidade fossem reconhecidos.

* Professor Doutor do Departamento de Direito Civil da Faculdade de Direito da Universidade de São Paulo (USP) e Professor Doutor da Faculdade de Direito do Centro Universitário das Faculdades Metropolitanas Unidas (FMU); Advogado em São Paulo

1 Afirmou ainda que, por meio de tal teoria, "alcança-se um dos cimos da dimensão jurídica. a princípio, obscura, esgarçando-se em direitos sem nitidez, com certa construtividade de protoplasma, como lhe argüiu karl gareis (das juristische wesen der autorrechte, büchs archiv für theorie und praxis des han-delsund wechselrechts, 35, 188), mas já permitindo a bluntschli, em 1853, nela fundar o direito de autor, teve a servi-la dezenas de escritores que acuradamente procuraram defnir os 'direitos da personalidade', em discussão e material assoberbantes (cf. f. m. mutzenbecher, zur lehre vom persönlichkeitsrecht, 63)" (Cf. Francisco Cavalcanti Pontes de Miranda . Tratado de Direito Privado . tomo VII . Rio de Janeiro : Borsoi, 1955 .p. 2) 
Ao versar sobre a proteção da pessoa, ${ }^{2}$ o Código Civil de 1916 tinha diversos dispositivos que - implicitamente $e^{3}$ admitiam os direitos da personalidade, sendo inegável a relevância jurídica de tal diploma legal que, ao tempo de sua elaboração - ao contrário de diversos países europeus - não ficou preso às suas tradições e teve, por meio de Clóvis Beviláqua, normas que traziam o que de mais avançado havia naquele período ${ }^{4}$, sendo

O Código Civil anterior adotava no Livro I o vocábulo "pessoas" e no Capítulo I "pessoas naturais" (atual Título I), mas utilizava o termo "homem" no artigo $2^{\circ}$ denominando homem e mulher, o legislador no Código Civil de 2002 empregou somente "pessoa" em todos os dispositivos (durante a tramitação no Senado Federal houve o uso do termo "ser humano". Na redação original, Clóvis Bevilaqua distinguia "pessoa natural" e "homem" dizendo que "as idéas de homem e de pessôa natural não coincidem em toda a sua extensão, por isso que pessôa natural é o homem numa determinada attitude na sociedade civil. A sociedade é o meio onde vive o homem; nesse meio, elle desenvolve a sua actividade em direcções diversas, protegido sempre pela ordem jurídica e, portanto, podendo agir como pessoa; mas o home pode ser encarado sob varias relações extranhas ou indifferentes ao direito. Não obstante, é certo que, perante o direito privado moderno, tendo desapparecido a instituição da escravidão, todo ser humano é pessôa" (Cf. Clóvis Bevilaqua . Theoria Geral do Direito Civil . $2^{\mathrm{a}}$ ed. . Rio de Janeiro : Francisco Alves, 1929. p. 8384). Destacamos ainda que o vocábulo "pessoa" vem do latim "persona" que, por sua vez deriva do grego "prósopon", que segundo Fábio Konder Comparato, representaria uma "oposição entre a individualidade própria de cada homem e as funções ou atividades por ele exercidas na vida social", que teria para os romanos um sentido de um rosto ou de uma máscara de teatro que individualizaria cada personagem (Cf. Fábio Konder Comparato. A afirmação histórica dos Direitos Humanos. São Paulo : Saraiva, 1999 . p. 15)

3 De fato, diversas normas versavam acerca dos direitos da personalidade a partir do artigo 1.537 do Código Civil de 1916, que assegurava o ressarcimento no caso de lesão ao direito à vida, "A indenização, no caso de homicídio, consiste: I - no pagamento das despesas com o tratamento da vítima, seu funeral e o luto da família; II - na prestação de alimentos às pessoas a quem o defunto os devia", assim como havia a previsão do direito à integridade física (Art. 1.538. "No caso de ferimento ou outra ofensa à saúde, o ofensor indenizará o ofendido das despesas do tratamento e dos lucros cessantes até o fim da convalescença, além de lhe pagar a importância da multa no grau médio da pena criminal correspondente § 1o Esta soma será duplicada, se do ferimento resultar aleijão ou deformidade, $\S 2$ o Se o ofendido, aleijado ou deformado, for mulher solteira ou viúva, ainda capaz de casar, a indenização consistirá em dotá-la, segundo as posses do ofensor, as circunstâncias do ofendido e a gravidade do defeito"; Art. 1.539. "Se da ofensa resultar defeito pelo qual o ofendido não possa exercer o seu oficio ou profissão, ou se lhe diminua o valor do trabalho, a indenização, além das despesas do tratamento e lucros cessantes até o fim da convalescença, incluirá uma pensão correspondente à importância do trabalho, para que se inabilitou, ou da depreciação que ele sofreu”), do direito à honra (Art. 1.547. "A indenização por injúria ou calúnia consistirá na reparação do dano que delas resulte ao ofendido. Parágrafo único. Se este não puder provar prejuizo material, pagarlhe-á o ofensor o dobro da multa no grau máximo da pena criminal respectiva"); Art. 1.548. "A mulher agravada em sua honra tem direito a exigir do ofensor, se este não puder ou não quiser reparar o mal pelo casamento, um dote correspondente à sua própria condição e estado: I - se, virgem e menor, for deflorada ; II - se, mulher honesta, for violentada, ou aterrada por ameaças ; III - se for seduzida com promessas de casamento ; IV - se for raptada") e do direito à liberdade (Art. 1.550. "A indenização por ofensa à liberdade pessoal consistirá no pagamento das perdas e danos que sobrevierem ao ofendido, e no de uma soma calculada nos termos do parágrafo único do art. 1.547".; Art. 1.551. "Consideram-se ofensivos da liberdade pessoal (art. 1.550): I - o cárcere privado; II - a prisão por queixa ou denúncia falsa e de má-fé; III - a prisão ilegal (art. 1.552)".

4 "Quando era professor em Recife, ensinando Legislação Comparada, Clóvis Beviláqua revelou-se exímio civilista. Ainda em 1896, publicou, na Revista Acadêmica da Faculdade de Direito do Recife, de que era o redator principal, o artigo 'O problema da codificação do Direito Civil Brasileiro'. Nele, começa defendendo a necessidade da codificação civil. Depois, passa a analisar as precedentes tentativas de se erigir um Código Civil Brasileiro, todas malsucedidas. Defende, em seguida, a noção de que o código deveria temperar tradição e inovação, clareza conceitual e flexibilidade, para ajustar-se às mudanças que o tempo traz, para que não caducasse logo, mas sem perder o lastro conferido pela experiência jurídica acumulada 
ainda possível registrar a existência de elementos que informam a teoria geral dos direitos da personalidade no Esboço e na Consolidação de Teixeira de Freitas. ${ }^{5}$

Asseverou Orlando Gomes, fundado em Gutteridge, que muitas das construções jurídicas da Europa continental foram introduzidas sem maior resistência e "o legislador pátrio, desdenhoso das condições materiais de existência do país, pôde, com mais facilidade, romper, em certos pontos, com as tradições do passado modificando as linhas arquitetônicas de importantes institutos jurídicos, e adotar teses avançadas da doutrina estrangeira, para acolher, afinal, certas conquistas interessantes da ciência jurídica". 6

Cumpre assinalar a importância, por meio da consagração dos direitos da personalidade, da ruptura de um paradigma estabelecido por relações exclusivamente negociais, na qual havia uma visão totalmente mecanicista do ser humano. ${ }^{7}$

A consagração dos direitos da personalidade por meio de normas constitucionais expressas em 1988 (art. 50, V, X e VIII, “a"8) e, posteriormente pelo Código Civil em vigor (Lei 10.406/02), a partir do artigo $11,{ }^{9}$ veio apenas sedimentar o que já era admitido implicitamente pelo sistema, assim como pelos doutrinadores e pela jurisprudência.

Miguel Reale, recordando os momentos decisivos do Código Civil em vigor, disse que "a tramitação do Projeto na Câmara dos Deputados foi longa, mas altamente proveitosa. Pode-se dizer que a sua aprovação na Câmara, com a redação final que lhe foi dada em 1984, representou a sua definitiva consolidação, com a elaboração

ao longo do tempo. Termina concluindo que a longa espera para que se obtivesse por fim o Código tão almejado teria sido mais fruto do esmero em aperfeiçoar o novo corpo legislativo do que resultado de negligência dos contratados para a empreitada. Antes, em 1893, já escrevera a obra Resumo das lições de Legislação Comparada sobre o Direito Privado, em que pudera provar sua visão ampla do Direito civil, com forte fundamentação nos alicerces do Direito Romano. Em 1896, trouxe a lume, ainda, duas outras obras de proa: Direito da Família e Direito das Obrigações. em 1899, lançou Direito das Sucessões. Resta claro, portanto, que, em 1899, quando recebe o convite do Ministro da Justiça e seu antigo colega de Direito em Recife, Epitácio Pessoa, para elaborar o Projeto do Código Civil Brasileiro, Clóvis já se revelara talhado para a tarefa" (Cf. Cássio Schubsky . Clóvis Beviláqua : um senhor brasileiro . São Paulo : Lettera.doc, 2010. p. 46-50)

5 Para Daisy Gogliano "Teixeira de Freitas, em sua Consolidação e no Esboço, não obstante deixe de inserir a disciplina dos direitos da personalidade, fornece subsidios e ensinamentos preciosos que vem informar a teoria geral desses direitos" (Cf. Daisy Gogliano . Direitos privados da personalidade . 1982 . Dissertação (mestrado em Direito Civil) - Faculdade de Direito, Universidade de São Paulo, São Paulo . p. 401)

6 Cf. Gutteridge apud Orlando Gomes . Raizes históricas e sociológicas do Código Civil brasileiro . $2^{\mathrm{a}}$ ed. . São Paulo : Martins Fontes, 2006. p. 19-20

7 Cf. Roxana Cardoso Brasileiro Borges. Disponibilidade dos Direitos de Personalidade e Autonomia Privada. São Paulo : Saraiva, 2005. p. 9-10.

$8 \quad$ Art. $5^{\circ}$ (...) V - é assegurado o direito de resposta, proporcional ao agravo, além da indenização por dano material, moral ou à imagem; $X$ - são invioláveis a intimidade, a vida privada, a honra e a imagem das pessoas, assegurado o direito a indenização pelo dano material ou moral decorrente de sua violação; XXVIII - são assegurados, nos termos da lei: a) a proteção às participações individuais em obras coletivas e à reprodução da imagem e voz humanas, inclusive nas atividades desportivas;

9 O dispositivo será comentado oportunamente 
de mandamentos que fixaram suas diretrizes fundamentais" e não olvidou da importância dos direitos aqui analisados ao afirmar que "a começar pela básica inovação dos 'direitos da personalidade' até a nova compreensão dos atos jurídicos, o que se dá é o abandono da pretensão de resolver os problemas jurídicos apenas graças a estritas categorias da Ciência do Direito, com abstração dos valores éticos e sociais". ${ }^{10}$

Após tais considerações, podemos adotar uma definição dos direitos da personalidade e seguimos aqui a de Rubens Limongi França, para quem tais direitos envolveriam "as faculdades jurídicas cujo objeto são os diversos aspectos da própria pessoa do sujeito, bem como seus prolongamentos e projeções". ${ }^{11}$

Ao utilizar o vocábulo "pessoa", em sua definição, Limongi França possibilitou que nela enquadrássemos tanto a pessoa física como a pessoa jurídica, uma vez que há fundamento legal, ${ }^{12}$ jurisprudencial $^{13}$ e doutrinário ${ }^{14}$ a atribuir às pessoas jurídicas a titularidade dos direitos da personalidade, no que couber.

Também Antônio Chaves indagava "Poderá falar-se em honra, sem se tratando de pessoas jurídicas?" e respondia que "a opinião da generalidade dos escritores é afirmativa" para concluir: "configura-se, portanto, o bem da honra também no que lhes diz respeito, bem ao qual não pode faltar a proteção penal". ${ }^{15}$

Portanto, é possível esboçar um conceito que, além de versar acerca dos titulares dos direitos da personalidade conduza igualmente ao exame de sua natureza jurídica.

Assim sendo, definimos os direitos da personalidade como direitos que versam sobre a própria pessoa e seus reflexos e que são reconhecidos à pessoa humana $\mathrm{e}$ atribuídos à pessoa jurídica.

Mesmo sem olvidar das lições de Carlos Alberto Bittar na primeira edição de sua obra "Direitos da Personalidade", ${ }^{16}$ na qual tal jurista criticava a visão positivista

10 Cf. Miguel Reale . História do novo Código Civil . São Paulo : Revista dos Tribunais, 2005 . p. 27

11 (Cf. p. 5)

12 Art. 52 da Lei 10.406/02 (Código Civil): “Aplica-se às pessoas jurídicas, no que couber, a proteção dos direitos da personalidade"

13 Súmula 227 do Superior Tribunal de Justiça - 8 de setembro de 1999 - DJ de 20 de outubro de 1999: “ $A$ pessoa jurídica pode sofrer dano moral".

14 Destacando a obra de diversos juristas da Faculdade de Direito da Universidade de São Paulo como Rubens Limongi França, Carlos Alberto Bittar, Silmara Juny de Abreu Chinellato e Antônio Chaves

15 Registrava, no entanto, como exceção, a opinião de Manzini e prosseguia "assim, Pontes de Miranda, invocando Specker e Ferrara: ao adquirir personalidade, as pessoas jurídicas adquirem tal direito, que não depende de substrato pessoal físico. Adriano De Cupis faz ver que ainda que as pessoas jurídicas não possam ter o 'sentimento' da própria dignidade, esta pode sempre refletir-se na consideração de terceiros" (Cf. Antônio Chaves . Lições de Direito Civil : Parte Geral 3 . São Paulo : Bushatsky - Edusp, 1972. p. 174)

16 "Configuram direitos subjetivos, que, para os autores positivistas (como De Cupis e Tobeñas), têm função especial em relação à personalidade, constituindo o minimum necessário e imprescindivel ao seu conteúdo. Constituem direitos cuja ausência torna a personalidade uma suscetibilidade completamente irrealizável, sem valor concreto: todos os outros direitos subjetivos perderiam o interesse para o individuo e a pessoa não existiria como tal (...) Consideram, no entanto, devem ser incluídos como direitos da personalidade 
e o próprio uso do termo "reconhecimento" pelos positivistas, recordamos que tal docente observava que só seria possível o reconhecimento de uma situação preexistente, ${ }^{17}$ existindo mesmo nesta uma diferença fundamental quanto à atribuição de direitos (derivada exclusivamente do texto legal e da vontade do legislador), ressaltando a percepção de que o fundamento dos direitos da personalidade é, de fato, jus-naturalista. ${ }^{18}$

Carlos Alberto Bittar, ao discorrer acerca do "Âmbito da Teoria dos Direitos da Personalidade" em 21 de março de 1995, na disciplina "Teoria Geral do Direito Civil: Direitos da Personalidade" ponderou que "a construção de qualquer conceito exige o uso correto das palavras" e que, mesmo para os positivistas, mais adequado seria o uso do vocábulo "atribuído" ao invés de "reconhecido", pois este teria maior sentido para aqueles que adotam a corrente jus-naturalista, eis que antes surge o direito e depois o Estado o reconhece, acrescentando que "tal posicionamento deve ser coerente para que seja mantida a lógica" no conceito. ${ }^{19}$

No que diz respeito ao fundamento dos direitos da personalidade, tal corrente é também integrada por Caio Mário da Silva Pereira, para quem "encontra, pois, boa sustentação, proclamar que a origem remota dos direitos da personalidade assenta no direito natural" e que "os direitos da personalidade, como categoria, são considerados como inerentes à pessoa humana, independentemente de seu reconhecimento pela ordem positiva". ${ }^{20}$

A atribuição de direitos, seguindo as lições de Carlos Alberto Bittar no curso de pós-graduação da Faculdade de Direito da Universidade de São Paulo, decorre da atuação do próprio Estado em sua função legislativa, sendo intuitivo que o fundamento da titularidade dos direitos da personalidade da pessoa jurídica decorre do texto legal.

apenas os reconhecidos pelo Estado, que lhes dá força jurídica. Não aceitam, pois, a existência de meros direitos inatos, que constituíram exigências de ordem moral, quando situado o observador no plano do direito positivo. Em conclusão, acentuam que todos os direitos subjetivos derivam do ordenamento positivo: daí, sua delimitação no direito positivo em cada caso" (Cf. Carlos Alberto Bittar . Os direitos da personalidade. Rio de Janeiro : Forense Universitária, 1989 . p. 6-7).

17 Na disciplina "Teoria Geral do Direito Civil: Direitos da Personalidade", que ministrou ao lado de Silmara Juny de Abreu Chinellato, durante o primeiro semestre de 1995, no curso de pós-graduação da Faculdade de Direito da Universidade de São Paulo.

18 "Situamo-nos dentre os naturalistas. Entendemos que os direitos da personalidade constituem direitos inatos - como a maioria dos escritores ora atesta - cabendo ao Estado apenas reconhecê-los e sancionálos em um ou outro plano do direito positivo" e "dotando-os de proteção própria, conforme o tipo de relacionamento a que se volte, a saber: contra o tipo de relacionamento a que se volte, a saber: contra o arbítrio do Poder público ou às incursões de particulares" (Cf. Carlos Alberto Bittar . Os direitos da personalidade. Rio de Janeiro : Forense Universitária, 1989 . p. 7).

19 Tivemos a honra de ser orientados pelo saudoso professor e, após seu falecimento em 1997, recebemos a orientação da Professora Titular Silmara Juny de Abreu Chinellato. Tais professores ministraram a disciplina "Teoria Geral do Direito Civil: Direitos da Personalidade" no curso de pós-graduação da Faculdade de Direito da Universidade de São Paulo durante o primeiro semestre de 1995, ano em que ingressamos no mestrado.

20 Cf. Caio Mário da Silva Pereira . Direito Civil : alguns aspectos de sua evolução . Rio de Janeiro : Forense, 2001 . p. $23-25$ 
De fato, adotamos a orientação de que a pessoa jurídica é uma realidade técnica, no sentido de uma técnica empregada pelo legislador e atribuída no ato constitutivo ou modificativo e no exercício da autonomia privada da pessoa jurídica, como sustentamos em nosso trabalho Direito de Autor em obra coletiva. ${ }^{21}$

É evidente que a expressão "no que couber" está relacionada às limitações que a pessoa jurídica enfrenta no exercício de tal direito, uma vez que inexiste um paralelismo perfeito ${ }^{22}$ (não podemos, à guisa de exemplo, falar em direito à vida da pessoa jurídica ou ainda em direito à integridade física).

Nos muitos debates entre os juristas que elaboraram o Código Civil em vigor, José Carlos Moreira Alves acolheu as observações de Clóvis do Couto e Silva, no sentido de aplicar às pessoas jurídicas os direitos da personalidade, como relata em sua obra "A Parte Geral do Projeto de Código Civil Brasileiro: subsídios históricos para o novo Código Civil brasileiro. ${ }^{23}$ "

Ainda, quanto às pessoas jurídicas ${ }^{24}$, assinalou Rabindranath Valentino Aleixo Capelo de Sousa que devem ser excluídos os direitos "que sejam inseparáveis da personalidade humana" 25 , mas certos direitos das pessoas jurídicas de Direito Público,

21 Cf. Antonio Carlos Morato . Direito de autor em obra coletiva . São Paulo : Saraiva, 2007. p. 39

22 A esse respeito, discorremos sobre os direitos da personalidade da pessoa jurídica tanto em nossa dissertação de mestrado como em nossa tese de doutorado, uma vez que não há como "negar a reparação do dano moral à pessoa jurídica, já que esta tem possibilidade de sofrer lesões em seu nome ou sua honra (até porque, o que dá azo a tal indenização vem a ser o fato de que a pessoa jurídica possua honra objetiva, que se projeta no seio da sociedade). A reparação do dano moral, na verdade, não exclui a pessoa jurídica, tanto por força do previsto na Constituição Federal (no art. $5^{\circ}, X$ ), como pelo disposto no Código de Defesa do Consumidor (art. $\left.6^{\circ}, V I\right)$, sendo consagrada na orientação predominante do Superior Tribunal de Justiça, por meio da Súmula 227 que admitiu que 'a pessoa jurídica pode sofrer dano moral' (Cf. Antonio Carlos Morato . A pessoa jurídica consumidora. São Paulo : Revista dos Tribunais, 2008. p. 233) ou ainda que "os direitos da personalidade também são atribuíveis à pessoa jurídica, encontrando-se base doutrinária, jurisprudencial e legal para tal afirmação (inclusive por força do art. 52 do vigente Código Civil - Lei n. 10.406/2002, que contribui definitivamente para afastar qualquer dúvida nesse sentido)" (Cf. Antonio Carlos Morato . Direito de autor em obra coletiva . São Paulo : Saraiva, 2007. p. XVIII).

23 "Acolho, também, o novo art. 23 das observações do Prof. Couto e Silva, o qual manda aplicar às empresas, no que couber, a proteção do direito de personalidade" e registra em nota de rodapé as observações de Couto e Silva "No tocante às empresas, o direito de personalidade geral adquire uma nova dimensão. Protege-se, através dele, o good will. A utilização dos testes neutros de mercadorias, por exemplo, pode ferir o direito geral de personalidade que se objetivava em dois conceitos fundamentais, para este setor do direito, good Will e nome (Michael R. Will, Warentext und Werbung, Heidelberg, 1968, p'. 67 e s.). No anteprojeto aparece com evidência a proteção ao nome, mas o mesmo não sucede com o good Will, o qual estaria contido na fórmula proposta, quando se alude à difusão de escritos que podem diminuir a respeitabilidade, não só da pessoa física, como também da pessoa jurídica. Poder-se-ia, enfim, para explicitar a abrangência do direito de personalidade, acrescentar um preceito pertinente às empresas. 'art. 23. Aplica-se às empresas, no que couber, a proteção do direito de personalidade'" (Cf. José Carlos Moreira Alves . A Parte Geral do Projeto de Código Civil Brasileiro : subsídios históricos para o novo Código Civil brasileiro . $2^{\mathrm{a}}$ ed. . São Paulo : Saraiva, 2003 . p. 40)

24 Utilizando em sua explicação o termo "pessoas colectivas", que predomina entre os portugueses.

25 Como os já mencionados direito à vida e integridade física, aos quais acrescenta - baseado em Heinrich Hubmann, Pierre Tercier e Peter Schwerdtner - o direito à integridade espiritual e anímica, o direito à liberdade de movimentos físicos, o direito à liberdade sexual, os direitos sobre o cadáver e sobre órgãos 
tais "como o direito ao bom nome ${ }^{26}$, o direito de associação, a inviolabilidade da sede e o segredo de correspondência" existem, ainda que sujeitas a um menor relevo de reserva da vida social e da própria liberdade de expressão - em razão de sua finalidade e interesse público - em comparação com as pessoas jurídicas de Direito Privado, pois estas "são, de certo modo, uma projecção, um substituto ou uma continuação de vontades humanas individuais". 27

2. Natureza jurídica e breve análise histórica

Prosseguindo, no que tange à natureza jurídica dos direitos da personalidade, o conflito entre o fundamento jus-naturalista e o jus-positivista é permanente e interfere em sua conceituação.

De acordo com Rubens Limongi França, em obra citada anteriormente, a natureza jurídica dos direitos da personalidade encontra seu fundamento no Direito Natural.

Francisco Amaral, na obra "Direito Civil : introdução", salientou, fundado nas lições de Jacques Ghestin e Gilles Goubeaux que os direitos da personalidade têm como natureza um direito subjetivo que tem um objeto inerente ao seu titular, que é a sua própria pessoa. ${ }^{28}$

Tal singularidade, inicialmente, dificultou o reconhecimento dos direitos da personalidade; pois a titularidade ensejaria a autorização para a prática do suicídio, ${ }^{29}$

e elementos dele destacáveis, os direitos à integridade da imagem física e do caráter, o direito à não perturbação das relações afetivo-pessoais, a dignidade humana, a saúde, aforça de trabalho, a força de vontade, os sentimentos e as aspirações (Cf. Rabindranath Valentino Aleixo Capelo de Sousa .O direito geral de personalidade. Coimbra: Coimbra, 1995. p. 596.)

26 "O nome, de modo geral, é elemento indispensável ao próprio conhecimento, porquanto é em tôrno dele que a mente agrupa a série de atributos pertinentes aos diversos indivíduos, o que permite a sua rápida caracterização e o seu relacionamento com os demais. De circunstâncias que tais, não discrepa o nome civil das pessoas fisicas, porque é através dele que os respectivos titulares são conhecidos e se dão a conhecer" (Cf. R. Limongi França. Do nome civil das pessoas naturais . São Paulo: Revista dos Tribunais, 1958. p. 22)

27 Cf. Rabindranath Valentino Aleixo Capelo de Sousa . op. cit. . p. 602-603.

28 "Embora se reconheça nos direitos da personalidade uma certa imprecisão, o que torna difícil integrá-los nas categorias dogmaticamente estabelecidas, é de consenso considerá-los direito subjetivo que tem, como particularidade inata e original, um objeto inerente ao titular, que é a sua própria pessoa, considerada, nos seus aspectos essenciais e constitutivos, pertinente à sua integridade física, moral e intelectual" (Cf. Francisco Amaral . Direito Civil: introdução . $7^{\mathrm{a}}$ ed. . Rio de Janeiro : Renovar, 2008. p. 285).

29 "Sendo evidente que o direito à vida não legitima o suicídio, apresentam-se como aspectos interessantes desse direito de personalidade os que resultam de relações jurídicas de natureza negocial que expõem uma das partes a riscos extremos. Até que ponto, pergunta Diez y Diez, é lícito arriscar a vida em exercícios perigosos e desnecessários pelo torpe afã de enriquecer? Toleram-se as atividades arriscadas em espetáculo de circo e se admitem as práticas desportivas, como a do pugilato, e as touradas, nas quais os participantes jogam com a própria vida" (Cf. Orlando Gomes . Introdução ao Direito Civil . 14 a ed. atualização e notas de Humberto Theodoro Júnior . Rio de Janeiro : Forense, 1999 . p. 154) 
argumento veementemente repudiado - entre outros autores - por Adriano De Cupis, ${ }^{30}$ e tal confusão conceitual só teria sua origem explicada (mas não justificada) em razão da natureza absoluta ${ }^{31}$ dos direitos da personalidade, tal como ocorre em relação aos direitos reais (estes, por óbvio, sempre dotados de um sentido patrimonial, ao contrário dos direitos da personalidade).

Parece inegável que um posicionamento de tal natureza não é justificável e só encontra explicação em uma percepção essencialmente patrimonial do objeto das relações jurídicas, própria do século XIX e da influência do Código Napoleônico de 1804, no qual o patrimônio ocupou papel central e, logicamente, a visão de disponibilidade dos direitos a influenciar a própria visão dos direitos da personalidade, contemporaneamente considerados como indisponíveis.

A importância dos direitos da personalidade e em seu compreensível fascínio teórico está, como salientou Walter Moraes na importância que confere à pessoa humana, antes esquecida pela hipertrofia do estudo da empresa e do Estado, possibilitando que a solidariedade e a dignidade humana estejam no centro de todo o ordenamento jurídico ${ }^{32}$.

Ainda que breve, a análise histórica dos direitos da personalidade permite a visão global de tais direitos.

Na lição de Fábio Maria De Mattia, os direitos da personalidade têm sua origem na reação ao domínio estatal sobre o indivíduo, por meio da teoria contratualista que identificou tais direitos como inatos ao homem. ${ }^{33}$

30 "La volontà del soggetto non può produrre l'estinzione del diritto alla vita neanche mediante l'atto materiale del suicidio. Coll'esecuzione di questo atto è immediatamente soppresso il bene della vita, e, con esso, il corrispondente diritto. Ma il diritto avente ad oggetto la vita non ricomprende la facoltà di abuso consistente nel potere di soppressione della vita stessa: quindi, il suicidion no costituisce atto di esercizio di un diritto" (Cf. Adriano De Cupis . I diritti della personalità . t. I . Milão : Giuffrè, 1959 . p. 96)

31 Como ensinou Walter Moraes, "os direitos de personalidade compõem um tipo de relação jurídica em tudo semelhante à relação de direito real, notadamente de propriedade. Não foi sem razão que nos primórdios da doutrina alguns teóricos conceberam os direitos de personalidade como uma espécie de propriedade in re ipsum, imaginando, outros, o conjunto dos bens inerentes à pessoa como um patrimônio moral do indivíduo. Foi o caso de Thibaut, Ortolan e Demolombe, entre outros. Com efeito, o direito de personalidade recai diretamente sobre o seu objeto, e não sobre atos de pessoas como sucede nas relações pessoais ou de obrigação. E assim é exercido no sentido de usar, fruir, e às vezes de dispor dos valores que seu objeto representa. Exercido tal direito em caráter de exclusividade, é poder que se opõe contra todos, isto é, contra um sujeito passivo universal devedor de respeito, abstenção ou preservação para com o valor pessoal. É, portanto, um direito absoluto. Eis a estrutura da relação jurídica de direito de personalidade. Trata-se pois de um direito absoluto como a propriedade, mas logo se distingue da propriedade porque esta é eminentemente prescindivel e aquele, sendo essencial, é coisa de que se não pode privar um sujeito" (Cf. Walter Moraes . Direitos da personalidade : estado da matéria no Brasil . Estudos de Direito Civil . Antônio Chaves (coord.). São Paulo : Revista dos Tribunais, 1979. p. 127)

32 "Tema cheio de dignidade e pureza jurídica este que encara e avalia diretamente a pessoa humana no terreno do direito, tem sido capaz de fascinar a quantos dele se aproxima (...) Não se trata porém apenas de um fascínio teórico, nem é isso o que mais conta. Importa considerar que neste parâmetro a ordem jurídica volta-se para o ser humano" (Cf. Walter Moraes . Direitos da personalidade : estado da matéria no Brasil . Estudos de Direito Civil . Antônio Chaves (coord.). São Paulo : Revista dos Tribunais, 1979. p. 128-129)

33 "Localiza-se a elaboração da teoria dos direitos da personalidade na reação surgida contra o domínio 
A teoria contratualista, difundida por Jean-Jacques Rousseau, vê um contrato originário entre o ser humano e a sociedade, em que aquele dispõe de seu natural direito à liberdade em prol da segurança oferecida pela sociedade.

No entanto, a sociedade corrompida pelo arbítrio de seus governantes reduz mais e mais a esfera de liberdade dos indivíduos, sendo célebre a frase de Rousseau que diz que o ser humano nasce livre, mas onde quer que se olhe se encontra escravizado ${ }^{34}$.

Celso Lafer sintetizou tal evolução, ao afirmar que "direitos inatos, estado de natureza e contrato social foram os conceitos que, embora utilizado com acepções variadas, permitiram a elaboração de uma doutrina do Direito e do Estado a partir da concepção individualista de sociedade e da história, que marca o aparecimento do mundo moderno. São estes conceitos os que caracterizam o jusnaturalismo dos séculos XVII e XVIII, que encontrou o seu apogeu na Ilustração", pois "a afirmação, pelo jusnaturalismo moderno, de um Direito racional, universalmente válido, teve efeitos práticos importantíssimos, seja na teoria constitucional, seja na obra de codificação que vieram a caracterizar a experiência jurídica do século XIX" 35

Há quem mencione que a origem dos direitos da personalidade estaria no Código de Hammurabi ${ }^{36}$ ou ainda no próprio Direito Romano. ${ }^{37}$

absorvente da tirania estatal sobre o individuo. A teoria contratualista supôs a existência de um Estado, perante o qual os indivíduos depunham sua liberdade em troca da proteção que dele receberiam, o que gerou a categoria dos direitos inatos" Cf. Fábio Maria De Mattia . Direitos da personalidade : aspectos gerais . Estudos de Direito Civil . Antônio Chaves (coord.) . São Paulo : Revista dos Tribunais, 1979, p. 99

34 "L'homme est né libre, et par-tout il est dans les fers. Tel se croit le maitre des autres, qui ne laisse pas d'être plus esclave qu'eux. Comment ce changement s'est-il fait? Je l'ignore. Qu'est-ce qui peut le rendre légitime? Je crois pouvoir résoudre cette question". (Cf. Jean-Jacques Rousseau. Du Contrat Social ou principes du Droit politique . Oeuvres complètes . t. III . Bibliothèque de La Pléiade, Paris: Gallimard, 1964, p. 351)

35 Acrescenta o autor, todavia, que estes efeitos contribuíram "para corroer o paradigma que os inspirou" e, "de fato, a codificação terminou por constituir-se em ponte involuntária entre o jusnaturalismo e o positivismo jurídico. Com efeito, uma das características do ideal do saber científico, nos séculos XVII e XVIII, foi a de uma ordenação exaustiva e universal de todas as diferenças possíveis, da qual deriva a idéia de sistema. O jusnaturalismo moderno corresponde a este ideal de um saber lógico-demonstrativo, e a obra de Pufendorf, que é do século XVII, representa, de maneira exemplar, a corporificação desta concepção de Direito como sistema. A idéia de sistema constitui um aspecto fundamental da contribuição do Direito Natural à jurisprudência européia, que deixou de limitar-se à exegese e à interpretação prudencial de textos singulares e passou a ter características de uma estrutura lógico-demonstrativa. Ora, transposta e positivada pelos códigos e pelas constituições a visão jusnaturalista de um Direito racional e sistemático, foi perdendo significado a idéia de outro Direito que não o Direito do Código e da Constituição. Por isso, o fundamento do Direito deixou de ser buscado nos ditames da razão e passou a afirmar-se como a vontade do legislador, independentemente de qualquer juizo sobre a conformidade desta vontade com a razão. Nesse sentido, o processo de laicização e sistematização do Direito terminou por confluir com o fenômeno da crescente positivação do Direito pelo Estado, que é outro processo característico da experiência jurídica no mundo moderno" (Cf. Celso Lafer . A reconstrução dos Direitos Humanos : um diálogo com o pensamento de Hannah Arendt . São Paulo : Companhia das Letras, 1988. p. 38-39)

36 Cf. Francisco Amaral . Direito Civil: introdução . $7^{a}$ ed. . Rio de Janeiro : Renovar, 2008. p. 285.

37 Daisy Gogliano asseverou que "os códigos antigos, de Hammurabi e de Manu não conheceram o instituto dos direitos privados da personalidade. No entanto, como embriões, em várias passagens, sentimos a preocupação com a preservação e a tutela de vários aspectos da personalidade. No direito romano, 
Todavia, ressaltamos que a ênfase no ser humano e em suas relações com o Estado só ocorreu por meio da atuação dos jus-filósofos do século XVIII e da difusão de suas ideias tanto pela independência norte-americana em 1776 como, principalmente, pela Revolução Francesa de 1789.

Os textos jurídicos que são frutos de tal período são invocados até hoje: a Constituição norte-americana de 1787 e a Declaração de Direitos do Homem e do Cidadão de 1791 .

3. Direitos da personalidade, direitos fundamentais e Direitos Humanos

O breve histórico que fizemos no tópico anterior permite que possamos analisar as relações entre os direitos da personalidade, os direitos e garantias fundamentais (também chamados de liberdades públicas) e os direitos humanos.

Inicialmente, podemos afirmar - invocando as lições de Carlos Alberto Bittar e de Rubens Limongi França ${ }^{38}$ - que os direitos da personalidade nada mais são do que a proteção aos direitos do ser humano sob o enfoque privado, ${ }^{39}$ seguindo a mesma corrente de José Castan Tobeñas. ${ }^{40}$

somente no periodo clássico afirma-se a noção de injúria, momento em que actio injuriarum desenvolvida pelo direito pretoriano passou a compreender qualquer espécie de ofensa, tanto física como moral. Sob Cornelius amplia-se a noção de injúria abrangendo aspectos privados. $O$ sentimento de dignidade do cidadão romano foi se aprimorando e afinando. A extensão dada à ação foi a abertura de um novo capitulo na história interna do povo romano". Cf. Daisy Gogliano . Direitos privados da personalidade . 1982 . Dissertação (mestrado em Direito Civil) - Faculdade de Direito, Universidade de São Paulo, São Paulo . p. 398-399)

38 'De nossa parte, preferimos a expressão 'direitos da personalidade', consagrada por quase um século, ou ainda 'direitos privados da personalidade', que apresenta, em certas circunstâncias, a vantagem de frisar o aspecto privado desses direitos, uma vez que, até a sua definição pelos juristas alemães, só lhes reconhecia a tutela pública, através do Direito Constitucional e do Direito Penal" (Cf. Rubens Limongi França . Manual de Direito Civil .v. 1. 2a ed. . São Paulo : Revista dos Tribunais, 1971 . p. 322)

39 Para Carlos Alberto Bittar divisam-se 'de um lado, os 'direitos do homem' ou 'direitos fundamentais' da pessoa natural, como objeto de relações de direito público, para efeito de proteção do indivíduo contra o Estado. Incluem-se, nessa categoria, normalmente, os direitos: à vida; à integridade fisica; às partes do corpo; à liberdade; o direito de ação. De outro lado, consideram-se 'direitos da personalidade' os mesmos direitos, mas sob o ângulo das relações entre particulares, ou seja, da proteção contra outros homens" (Cf. Carlos Alberto Bittar . Os direitos da personalidade . Rio de Janeiro : Forense Universitária, 1989 . p. 23) Os ensinamentos de Carlos Alberto Bittar e José Castan Tobeñas foram igualmente seguidos por Leonardo Estevam de Assis Zanini, que destacou que os "direitos da personalidade são examinados sob o prisma das relações privadas, da proteção contra outros homens, enquanto que os direitos fundamentais são direitos públicos que objetivam a proteção do indivíduo contra atos do Estado" (Cf. Leonardo Estevam de Assis Zanini . Direitos da personalidade : aspectos essenciais . São Paulo : Saraiva, 2011. p. 62)

40 "La teoria de los derechos de la personalidad pertenece fundamentalmente al Derecho privado. Ha respondido al propósito de que sean reconocidos y proclamados tales derechos como uma nueva especie de derechos privados, dotados de protección civil. Por el contrario, la teoria de los derechos del hombre se preocupa, sobre todo, de su tutela pública, aspirando a poner al individuo bajo la protección del Derecho político" (Cf. José Castan Tobeñas . Los derechos de la personalidad . Madri :Instituto Editorial Reus, 1952. p. 13) 
Eunice Aparecida de Jesus Prudente, em sua tese de doutorado intitulada "Direito à personalidade integral: cidadania plena", estudou as relações entre os direitos da personalidade e as liberdades públicas considerando que mesmo "uma pesquisa mais aprofundada sobre os direitos de personalidade em face do Estado, deve ser iniciada pelo reconhecimento desses mesmo direitos". ${ }^{41}$

Paulo Cardoso Correia da Mota Pinto, logo após registrar que tais direitos são essenciais, "uma vez que a própria personalidade humana quedaria descaracterizada se a proteção que eles concedem não fosse reconhecida pela ordem jurídica", acentua que "a essencialidade explica que os direitos de personalidade sejam em regra considerados direitos fundamentais" e que "são, neste sentido, o correspondente privatístico para a tutela de certos bens da personalidade pela Constituição, tutela que, como se sabe, não opera só no confronto de entidades públicas, mas também de terceiros particulares". ${ }^{42}$

Utilizamos em nossas aulas, em muitas ocasiões, um exemplo que ilustraria as relações entre os direitos da personalidade, os direitos e garantias fundamentais e os direitos humanos. ${ }^{43}$

Imaginemos que temos três observadores de uma mesma estátua em um museu e que cada um deles observa tal estátua sob ângulos distintos, imaginando ainda que a estátua consistiria no próprio objeto (a pessoa humana ou natural e, no que couber, a pessoa jurídica) e que cada observador seria um ramo do Direito.

Assim, o Direito Civil, mediante os direitos da personalidade, trataria da questão sob o âmbito privado, regulando as relações entre os particulares, enquanto o Direito Constitucional disciplinaria as relações entre a pessoa e o Estado, coibindo os abusos deste por meio das liberdades públicas e os Direitos humanos fariam parte do

41 E isso porque, de acordo com Eunice Aparecida de Jesus Prudente, “a percepção pelo homem de sua própria individualidade foi historicamente concomitante com inquietações em torno das questões da liberdade, da possível igualdade entre os homens e questionamentos em torno do exercício do poder político" e, "finalmente, seu reconhecimento pelo Estado, com criação de normas jurídicas específicas, em proteção e pelo desenvolvimento dessa individualidade humana e suas diversificadas emanações (direitos da personalidade)" (Cf. Eunice Aparecida de Jesus Prudente. Direito à personalidade integral : cidadania plena. 1996. Tese (doutorado em Direito do Estado) - Faculdade de Direito, Universidade de São Paulo.)

42 Cf. Paulo Cardoso Correia da Mota Pinto. Os direitos de personalidade no Código Civil de Macau . Boletim da Faculdade de Direito da Universidade de Coimbra . Coimbra . v. 76. p. 205-50, 2000. p. 207

43 Embora tal exemplo tenha sido retirado da imaginação, ele encontra base em conceitos oriundos da Doutrina (Orlando Gomes, Carlos Alberto Bittar, Fábio Maria De Mattia). A esse respeito, Fábio Maria De Mattia recordava as lições de Orlando Gomes no sentido de que os "os direitos da personalidade são os próprios direitos do homem encarados sob outra perspectiva", assim como os direitos do homem "são direitos públicos, como direitos da personalidade são direitos privados. Os direitos individuais são atribuídos, na esfera politica, para proteger a personalidade contra o arbitrio do Estado, enquanto a esses mesmos direitos, na esfera privada se concede a proteção para resguardá-los de atentados a que está exposta pela ação inconsiderada de outro indivíduo" (Cf. Fábio Maria De Mattia . Direitos da personalidade : aspectos gerais . Estudos de Direito Civil . Antônio Chaves (coord.) . São Paulo : Revista dos Tribunais, 1979 . p. 103). 
Direito Internacional Público, no qual os Estados - entre si - exigiriam o respeito aos direitos da pessoa humana.

É claro que tal explicação é uma simplificação (basta lembrar que temos gerações de Direitos como veremos a seguir), mas ajuda a entender o problema que foi posto pela superposição de tutelas.

Historicamente, também podemos considerar válidas para o nosso sistema as observações de Antônio Menezes Cordeiro, quanto aos direitos da personalidade terem uma tutela inicialmente publicística, ${ }^{44}$ tendo as normas civis progredido mais lentamente. ${ }^{45}$ Acrescentou, quanto ao Código Civil português, ${ }^{46}$ que "a publicação do Código Civil não provocou, de imediato, uma especial concretização dos direitos de personalidade" e, pelo contrário "foi mesmo recebido com frieza", tendo os doutrinadores portugueses modificado posteriormente seu posicionamento quanto a tais direitos ${ }^{47}$ e que “a jurisprudência portuguesa - de resto: tal como a doutrina - só despertou lentamente para os direitos da personalidade" e "não obstante esse arranque tardio, ela assegurou - e, em diversos campos, assegura - a vanguarda do processo de concretização dos institutos aqui em causa", 48

44 E, em tal sentido, tais observações podem ser complementadas por Elimar Szaniawski: “A moderna doutrina que se desenvolveu em torno da teoria do direito geral de personalidade se opõe à chamada doutrina tradicional, cuja tese afirma que os direitos fundamentais orginários devem apenas se tornar pretensões de defesa contra ataques às pessoas oriundos do Estado. Este pensamento se constitui em uma visão estreita que, infelizmente, ainda vinha sendo professada por alguns professores de direito público na década de cinqüenta. É evidente que a principal função dos direitos fundamentais se manifesta em relação à defesa das liberdades do estado de direito, situando-se em primeiro plano, a proteção dos cidadãos contra os atentados praticados pelo próprio Estado. Mas os direito fundamentais, inseridos na Constituição, possuem um campo de atuação muito mais amplo do que a simples proteção do indivíduo contra o Estado" (Cf. Elimar Szaniawski. Direitos da Personalidade e sua Tutela . São Paulo : Revista dos Tribunais, 1993 .p. 57)

45 "Os direitos de personalidade conhecem, recentemente, um surto doutrinário e jurisprudencial (...) $O$ Direito Civil português despertou tarde para o problema", pois "na tradição portuguesa, os direitos das pessoas obtinham uma tutela publicística. Podemos, a tal propósito, referir os institutos do direito de petição, da tutela penal e da proteção constitucional" e mencionou as penas oriundas das Ordenações, bem como as Constituições Portuguesas e sua inspiração francesa para concluir que "na lei civil, a progressão foi mais lenta" (Cf. António Menezes Cordeiro . Os direitos de personalidade na civilística portuguesa. Revista da Ordem dos Advogados . Lisboa. v. 61. n.3 . 2001 . p. 1229-1232)

46 Existe, portanto, considerável diferença quanto ao panorama imediatamente posterior à edição da Lei 10.406/02 (Código Civil), ainda que exista um paradoxo - quando discutimos aqui a questão da publicização dos direitos da personalidade - no sentido de que tal função já tivesse sido cumprida em tal ponto, seja em relação aos doutrinadores ou à jurisprudência pelo próprio texto constitucional a partir de 5 de outubro de 1988 , por meio do art. $5^{\circ}$, V e X e de sua aplicação direta por meio da teoria da recepção ao Código Civil de 1916. Não se aceitou a ideia de que as normas constitucionais seriam dirigidas ao legislador e não aos julgadores e que estes deveriam aguardar a edição de um novo Código Civil, o que só ocorreu com a Lei $10.406 / 02$.

47 Cf. António Menezes Cordeiro . Os direitos de personalidade na civilística portuguesa. Revista da Ordem dos Advogados . Lisboa. v. 61. n. 3 . 2001 . p. 1243.

48 Cf. António Menezes Cordeiro. op. cit.. p. 1245. 
Entre os franceses, a jurisprudência contribuiu efetivamente para a consolidação dos direitos da personalidade (assegurando o ressarcimento de danos extrapatrimoniais à honra e ao nome, como enfatizou Geneviève Viney. ${ }^{49}$

Arturo Valencia Zea, citado por Fábio Maria De Mattia, afirmou que careceria de sentido criar uma divisão entre os direitos da personalidade e os direitos humanos, no sentido de afirmar que aqueles tratariam das relações privadas e que estes tratariam das relações entre particulares e o Estado..$^{50}$

Apesar de um tanto extremada em sua manifestação (quando Arturo Valencia Zea afirma que careceria de qualquer sentido), lembramos que nada impede que utilizemos concomitantemente o Código Civil (art. 11 e s.s.), a Constituição Federal (essencialmente o art. $5^{\circ}$ ) e qualquer Tratado que tenha ingressado em nosso sistema (por exemplo, o Pacto de San José da Costa Rica) para a defesa de uma pessoa diante do Estado ou de outros indivíduos.

Cumpre salientar ainda a relevância dos tratados que versem sobre os direitos protetivos da pessoa humana em nosso ordenamento jurídico e, ainda que formalmente - tais tratados ingressem no sistema como normas infraconstitucionais, sua relevância foi reconhecida pelo Congresso Nacional por meio da Emenda Constitucional no 45 (aprovada em 08/12/2004) e pelo Supremo Tribunal Federal por meio da Súmula Vinculante $n^{\circ} 25^{51}$ (aprovada pelo Tribunal Pleno em 16/12/2009) que estabeleceu o entendimento de que "é ilícita a prisão civil de depositário infiel, qualquer que seja a modalidade do depósito ${ }^{52}$ ".

49 “Cependant, les applications les plus fréquentes, par la jurisprudence actuelle, des mesures tendant à faire cesser les troubles invoqués, concernent la protection des droits de la personnalité. Elles sont ordonnées par exemple pour mettre fin à des atteintes à l'honneur ou à la réputation d'une personne ou à on nom. Mais c'est principalement à propos des atteintes à la vie privée, notamment par la voie de la presse, du livre, de la radio-diffusion ou d'enregistrements sur disques ou cassetes, que l'usage de ce type de procédés s'est développé ces dernières années" (Cf. Geneviève Viney . Traité de Droit Civil : les obligations : la responsabilité : effets . Paris : L.G.D.J., 1988 . p. 42)

50 "Arturo Valencia Zea sustenta que os direitos humanos são os mesmos direitos da personalidade. E justifica sua posição, pois, em primeiro lugar, qualquer direito subjetivo protege-se não apenas contra os atentados dos demais, mas, também, contra os atentados efetuados pelo Estado e em segundo lugar carece de sentido dar um nome a um direito quando relaciona-se com o Estado e um nome diferente quando refere-se às demais pessoas" (Cf. Fábio Maria De Mattia . Direitos da personalidade : aspectos gerais . Estudos de Direito Civil . Antônio Chaves (coord.). São Paulo : Revista dos Tribunais, 1979 . p. 103)

51 Súmula Vinculante n. 25 - Ilicitude - Prisão Civil de Depositário Infiel - Modalidade do Depósito - PSV 31 - DJe n. 27/2010 - Tribunal Pleno de 16/12/2009 - DJe n. 238, p. 1, em 23/12/2009 - DOU de 23/12/2009, p. 1

52 Não há, no Código Civil em vigor (artigos 1361 a 1368), que disciplina a propriedade fiduciária, nenhuma alusão à possibilidade do credor requerer a conversão do pedido de busca e apreensão em ação de depósito, possibilitando a prisão civil caso o bem alienado fiduciariamente não fosse encontrado ou não se achasse na posse do devedor, como consta no art. $4^{\circ}$ do Decreto-Lei n. 911/69. Mesmo na hipótese de inexecução obrigacional (artigo 1.363 do Código Civil), há somente a responsabilidade do devedor quanto ao seu patrimônio. Álvaro Villaça Azevedo, ainda antes da aprovação do Código Civil atual enfatizava que o credor fiduciário deveria "correr os riscos normais do direito de propriedade, tal a perda do objeto, em mãos de outrem, sem culpa deste, é o princípio de que a coisa perece para o dono (res perit domino) contido 
Tal súmula aparentemente teria contrariado o texto expresso do art. $5^{\circ}, \mathbf{L X V I I}$ da Constituição Federal que determinava que "não haverá prisão civil por dívida, salvo a do responsável pelo inadimplemento voluntário e inescusável de obrigação alimentícia e a do depositário infiel", mas sua edição não violou o seu sentido, na medida em que desde a aprovação da Constituição Federal - o art. $5^{\circ}, \S \mathbf{2}^{\mathbf{0}},{ }^{53}$ presente no mesmo texto normativo, teve como escopo a ampliação dos direitos humanos previstos em tratados, ainda que o Supremo Tribunal Federal só tenha se posicionado definitivamente após a Emenda Constitucional n. 45 (com a inserção do $\S 3^{\circ}$ no art. $5^{\circ}$ do texto constitucional).

De fato, o Pacto de San José da Costa Rica, no art. $7^{\circ}$, 7. determinou que "ninguém deve ser detido por dívidas. Este princípio não limita os mandados de autoridade judiciária competente expedidos em virtude de inadimplemento de obrigação alimentar". Assim, reduzindo a uma a hipótese de prisão civil por dívidas houve uma ampliação do direito à liberdade de locomoção ${ }^{54}$ e a Súmula Vinculante n. 25 do Supremo Tribunal Federal foi editada em plena consonância com o sentido e objetivos originais

no Código Civil brasileiro" para concluir que não existiria dentro do instituto da alienação fiduciária em garantia "a figura do depositário, pois, em verdade, o alienante (fiduciante) é o proprietário, porque, desde o início negocial, sofre ele o risco da perda do objeto" e "ninguém pode ser condenado, portanto, como depositário infiel, se correr o risco da perda da coisa; isto porque, reafirme-se, o depositário deve guardar bem alheio, e não bem próprio" (Cf. Álvaro Villaça Azevedo . Prisão Civil por Dívida . 2a ed. . São Paulo : Revista dos Tribunais, 2000 .p. 122-124).

53 Art. $5^{\circ}, \S \mathbf{2}^{\mathbf{0}}$ da Constituição Federal: "Os direitos e garantias expressos nesta Constituição não excluem outros decorrentes do regime e dos princípios por ela adotados, ou dos tratados internacionais em que a República Federativa do Brasil seja parte". Ainda, quanto à inclusão dos tratados internacionais no dispositivo constitucional, os comentários de Flávia Piovesan, para quem "ao efetuar tal incorporação, a Carta está atribuindo aos direitos internacionais uma natureza especial e diferenciada, qual seja, a natureza de norma constitucional" (Cf. Flávia Piovesan . Direitos Humanos e o Direito Constitucional Internacional . São Paulo : Max Limonad, 1996 . p. 317-318).

54 Entre as diversas obras que defenderam a natureza constitucional das normas de tratados que versem sobre direitos humanos, Valério de Oliveira Mazzuoli, frisou que se houver conflito entre norma incorporada por tratado e o texto constitucional "terá primazia, segundo a nossa orientação, a norma que der prevalência aos direitos humanos, e que, no caso da infidelidade depositária, é o Pacto de San José da Costa Rica. Curiosamente, no caso daquela outra hipótese excepcionada pelo inciso LXVII do art. $5^{\circ}$ da nossa Constituição, a situação é diversa. A Carta Magna de 1988 somente permite seja preso o devedor de alimentos se for ele responsável pelo inadimplemento voluntário e inescusável da obrigação alimentar. Tal redação difere da do Pacto de San José da Costa Rica que, depois de estabelecer a regra genérica de que 'ninguém deve ser detido por dividas', acrescenta que 'este princípio não limita os mandados de autoridade judiciária competente expedidos em virtude do inadimplemento de obrigação alimentar' (art. $\left.7^{\circ}, n^{\circ} 7\right)$, permitindo assim sejam expedidos mandados de prisão pela autoridade competente em virtude de qualquer inadimplemento de obrigação alimentar. A situação é inversa porque a Constituição de 1988, como se viu, foi mais além: inseriu na exceção respeitante ao devedor de alimentos, explicitamente, adjetivação restringente, que, sem sombra de dúvida, neste ponto, é a Constituição brasileira mais benéfica do que o tratado, pois melhor protege a liberdade individual, devendo então prevalecer, neste ponto, sobre o referido Pacto" (Cf. Valério de Oliveira Mazzuoli . Prisão civil por dívida e o Pacto de San José da Costa Rica : de acordo com o novo Código Civil brasileiro (Lei n. 10.406/2002) . Rio de Janeiro : Forense, 2002. p. 194 195) 
do constituinte, que não negligenciava - inclusive - as complexidades que envolviam o Pacto citado. ${ }^{55}$

Voltando à tricotomia anteriormente analisada, destacamos que muito mais significativo do que debatermos qual área deveria prevalecer ou ainda tentar estabelecer um critério para uma rígida divisão entre os diversos ramos jurídicos que tutelam a dignidade da pessoa humana (direitos da personalidade, os direitos humanos e as liberdades públicas (ou direitos fundamentais)), seria realmente cuidarmos da efetivação de direitos de tal magnitude que interessam a toda a espécie humana.

Convém destacar o fato de que, da mesma forma, o Direito Penal tutela os direitos da personalidade (vida, integridade física, honra, entre os muitos exemplos que podem ser citados), sem olvidar do direito à intimidade, recordando aqui a obra de

55 Tal preocupação foi demonstrada durante o debate realizado na audiência pública presidida pelo Deputado Federal Antonio Marques da Silva Mariz, em que este observou que "antes de encerrar essa parte da reunião, de levantar ainda duas questões, se me for permitido. A primeira é relativa ao Pacto de São José da Costa Rica, que me parece que não foi referido pelo expositor. A segunda é relativa à Convenção da ONU sobre crimes de tortura. No primeiro caso, trata-se de um pacto que cuida da criação de um Tribunal Internacional dos Direitos da Pessoa Humana, que se inscreve na linha tradicional da política brasileira exterior, naturalmente marcada pelo hiato que viveu o País durante o periodo autoritário. O Brasil tem uma história de participação nas lutas em defesa dos direitos humanos. Desde a primeira Constituição, a de 1824, as Cartas politicas brasileiras inserem em seu texto a declaração de direitos e garantias. A de 1824 chega a repetir, quase que textualmente, dispositivos das declarações francesas, inclusive a de 1793, a mais radical delas, e assim sucessivamente em 1891, em 1934, em 1946, também com o lapso de 1937, quando tivemos uma Carta autocrática. O Brasil antecipou-se a muitas nações modernas com a Constituição de 1934, no reconhecimento dos direitos econômicos, sociais e culturais. E também está dentro da história da luta americana por esses direitos. Neste continente, inúmeros atos, da maior repercussão universal, foram produzidos. Desde a Declaração da Virgínia, de 1776, até os atos mais recentes, aqui citados pelo Prof. Antônio Augusto Cançado Trindade. A Constituição mexicana, apenas para exemplificar, foi a primeira no mundo a consagrar esses chamados direitos sociais, culturais e econômicos. A Convenção Americana dos Direitos e Deveres do Homem se antecipou à própria Declaração Universal dos Diretos Humanos proclamada, em Paris, em 1948. E assim, em inúmeras outras ocasiões. Há até referências, feitas por Dunshee de Abranches - que foi, muitas vezes, representante do Brasil nessas conferências - a uma Corte de Justiça Interamericana, que funcionou por um prazo relativamente curto, cerca de dez anos, nos países centroamericanos, e que admitiu, pela primeira vez, na história do Direito Internacional Público, a pessoa humana como sujeito de direito capaz de acionar uma corte internacional. Então, esse pacto de São José da Costa Rica estabelece a possibilidade jurídica de criação de um Tribunal Internacional dos Direitos da Pessoa Humana, e completa, com isso, o quadro moderno dos direitos humanos, que se ressente, justamente, da falta de órgãos jurisdicionais capazes de dar eficácia aos direitos definidos nas declarações. O Brasil, segundo estou informado, subscreveu, finalmente, o Pacto de São José da Costa Rica, e o Poder Executivo teria encaminhado ao Congresso a ratificação deste pacto" (ASSEMBLÉIA NACIONAL CONSTITUINTE (ATAS DE COMISSÕES) - p. 94 - Direitos e Garantias Individuais, em Quinta Reunião de Audiência Pública realizada em 29 de abril de 1987, sob a Presidência do Senhor Constituinte Antonio Mariz, com as presenças dos Senhores Constituintes: José Fernandes, Maguito Vilela, Narciso Mendes, José Mendonça Bezerra. Ubiratan Spinelli, Eliel Rodríguez, Costa Ferreira, Antônio Câmara, Darcy Pozza, Lúcia Vânia, Dirce Tutu Quadros, Lúcia Braga, Vivaldo Barbosa e Délio Braz. Havendo número regimental o Senhor Presidente declarou abertos os trabalhos, dispensada a leitura da Ata da reunião anterior, tendo sido considerada aprovada. O Senhor Presidente comunicou ao Plenário a presença do Professor Antonio Augusto Cançado Trindade, Consultor-Jurídico do ltamarati, primeiro expositor para falar sobre "Direitos e Garantas Individuais no Plano Internacional"). 
Paulo José da Costa Júnior intitulada "O direito de estar só: tutela penal da intimidade" 56 e importantes comentários como os de Ivette Senise Ferreira. ${ }^{57}$

De fato, o conceito de "essencialidade" (com a personalidade humana descaracterizada se a proteção não fosse reconhecida pela ordem jurídica) próprio dos direitos da personalidade, salientada anteriormente por diversos autores e, como destacamos, por Paulo Cardoso Correia da Mota Pinto justifica também a tutela penal, considerando que "assim se compreende, ainda, que os direitos da personalidade tutelem bens que são, na grande maioria dos casos, protegidos penalmente, integrando aquele 'mínimo ético' cuja violação o direito penal deve sancionar". ${ }^{58}$

Consideramos muito oportuno - em tal contexto - registrar os ensinamentos de Francisco Amaral quanto à relevância de uma tutela jurídica interdisciplinar ou, em nas palavras de tal autor, "mais reforçada", pois "da natureza do próprio objeto, vale dizer, da sua importância, decorre uma tutela jurídica 'mais reforçada' do que a generalidade dos demais direitos subjetivos, já que se distribui nas esferas de ordem constitucional, civil e penal". 59

Retornando à outra questão que levantamos anteriormente e que versa a respeito das denominadas "gerações de direitos", destacamos que Manoel Gonçalves Ferreira Filho mencionou que a união de tais gerações completaria o lema da Revolução Francesa: liberdade, igualdade e fraternidade e que a origem do termo "gerações" é devida ao jurista tcheco-francês ${ }^{60}$ Karel Vasak que "na abertura dos cursos do Instituto Internacional dos Direitos do Homem, em 1979, apontou a existência dessa terceira geração, chamando-os de direitos de solidariedade", ${ }^{61}$ expressão que teve sua origem

56 Segundo Paulo José da Costa Júnior "na expressão 'direito à intimidade' são tutelados dois interesses, que se somam: o interesse de que a intimidade não venha a sofrer agressões e o de que não venha a ser divulgada. O direito, porém, é o mesmo. O que pode assumir uma gama diversa é o interesse protegido pelo direito. São duas esferas de interesses, abarcadas no mesmo raio de proteção do mesmo direito. No âmbito do direito à intimidade, portanto, podem ser vislumbrados estes dois aspectos: a invasão e a divulgação não autorizada da intimidade legitimamente conquistada. Em termos de conteúdo, todavia, não deve prevalecer a distinção" (Cf. Paulo José da Costa Júnior . O direito de estar só : tutela penal da intimidade . $4^{a}$ ed. . São Paulo : Revista dos Tribunais, 2007. p. 27)

57 Cf. Ivette Senise Ferreira . A intimidade e o direito penal. Revista Brasileira de Ciências Criminais, São Paulo, v. 5, p. 96, 1994.

58 Cf. Paulo Cardoso Correia da Mota Pinto . Os direitos de personalidade no Código Civil de Macau . Boletim da Faculdade de Direito da Universidade de Coimbra . Coimbra . v. 76. p. 205-50, 2000 . p. 207

59 Cf. AMARAL, Francisco. Direito civil: introdução. 7. ed. . Rio de Janeiro : Renovar, 2008. p. 285.

60 Karel Vasak nasceu na antiga Tchecoslováquia (Estado que existiu até 1992 e que correspondia às atuais República Tcheca e Eslováquia) e posteriormente mudou para a França em razão da invasão da antiga União Soviética em 1968 (após a conhecida Primavera de Praga), país onde estudou Direito e obteve outra nacionalidade (Disponível em : <http://en.wikipedia.org/wiki/Karel_Vasak $>$. Acesso em: 15 set. 2007.).

61 Tais informações foram retiradas pelo autor da obra de Robert Pelloux (Vrais et faux droits de l'homme . Revue du Droit Public et de la Science Politique en France et à l'étranger. Paris . Lib Générale, 1981, n. 1 . p. 58) e, prossegue Manoel Gonçalves Ferreira Filho dizendo que "o reconhecimento dos direitos sociais não pôs termo à ampliação do campo dos direitos fundamentais. Na verdade, a consciência de novos desafios, não mais à vida e à liberdade, mas especialmente à qualidade de vida e à solidariedade entre os 
ainda mais detalhada por Antônio Cançado Trindade durante uma palestra proferida na $V$ Conferência Nacional de Direitos Humanos, realizada em maio de $2000{ }^{62}$

Na visão de Paulo Bonavides "os direitos fundamentais passaram na ordem institucional a manifestar-se em três gerações sucessivas", o que traduziria, segundo o autor, inegavelmente "um processo cumulativo e quantitativo". ${ }^{63}$

Voltando ao paralelo estabelecido em relação aos direitos da personalidade, esclarecemos que tais direitos relacionam-se - inicialmente - a uma primeira geração de direitos, denominados de direitos de liberdade ${ }^{64}$, que exigem do Estado um comportamento

seres humanos de todas as raças ou nações, redundou no surgimento de uma nova geração - a terceira - a dos direitos fundamentais. São estes chamados, na falta de melhor expressão, de direitos de solidariedade, ou fraternidade. A primeira geração seria a dos direitos de liberdade, a segunda, dos direitos de igualdade, a terceira, assim, completaria o lema da Revolução Francesa: liberdade, igualdade, fraternidade" (Cf. Manoel Gonçalves Ferreira Filho . Direitos Humanos fundamentais . São Paulo : Saraiva, 1996. p. 57)

${ }^{62} \mathrm{Na}$ ocasião, Antônio Cançado Trindade afirmou que não aceitava, "de forma alguma a concepção de Norberto Bobbio das teorias de Direito. Primeiro, porque não são dele. Quem formulou a tese das gerações de direito foi o Karel Vasak, em conferência ministrada em 1979, no Instituto Internacional de Direitos Humanos, em Estrasburgo Pela primeira vez, ele falou em gerações de direitos, inspirado na bandeira francesa: liberté, egalité, fraternité. A primeira geração, liberté: os direitos de liberdade e os direitos individuais. A segunda geração, egalité: os direitos de igualdade e econômico-sociais. A terceira geração diz respeito a solidarité: os direitos de solidariedade. E assim por diante. Eu sou seu amigo pessoal, foi meu professor. Fui o primeiro latino-americano a ter o diploma do Instituto. Foi meu examinador, é meu amigo pessoal e agora tive a grata satisfação de colaborar com um artigo em homenagem a ele, publicado pela UNESCO, em Paris. Sou isento para falar sobre o assunto. Sou amigo dele e não concordo com a tese que ele apresentou pela primeira vez em 1979, e que Norberto Bobbio copiou. Para falar dos seguidores de Norberto Bobbio, aqui, neste País, como em todos os países da América Latina, temos a mania de copiar ipsis Iiteris, como se fosse a última palavra, o que dizem os europeus. Eu não estou de acordo com essa tese de Norberto Bobbio e do meu querido amigo Karel Vasak. Por que razões? Tenho relação de amizade com seguidores dessa tese aqui no Brasil, mas não estou de acordo com seus fundamentos. Em primeiro lugar, essa tese das gerações de direitos não tem nenhum fundamento jurídico, nem na realidade. Essa teoria é fragmentadora, atomista e toma os direitos de maneira absolutamente dividida, o que não corresponde à realidade. Eu conversei com Karel Vasak e perguntei: 'Por que você formulou essa tese em 1979?'. Ele respondeu: 'Ah, eu não tinha tempo de preparar uma exposição, então me ocorreu fazer alguma reflexão, e eu me lembrei da bandeira francesa'-ele nasceu na velha Tchecoslováquia. Ele mesmo não levou essa tese muita a sério, mas, como tudo que é palavra 'chavão', pegou. Ai Norberto Bobbio começou a construir gerações de direitos etc." (Cançado Trindade Questiona a Tese de "Gerações de Direitos Humanos" de Norberto Bobbio . DHNet - Direitos Humanos na Internet . Disponível em: <http://www.dhnet.org.br/ direitos/militantes/cancadotrindade/cancado_bob.htm>. Acesso em: 15 set. 2007.).

63 Cf. Paulo Bonavides . Curso de Direito Constitucional . 19a ed. . São Paulo : Malheiros, 2006. p. 563.

64 Em sua Introdução à jurisprudência do Tribunal Constitucional Federal Alemão, Leonardo Martins assinalou que " $O$ rol de direitos fundamentais começa com a máxima segundo a qual todos têm o direito ao livre 'desdobramento’(desenvolvimento) da personalidade (Art. 2 I GG). Trata-se de uma tutela subsidiária (lex generalis) da liberdade individual, consubstanciada nos chamados direitos da personalidade e na liberdade geral de ação. Seguem dois outros direitos no Art. 2 II 1 GG: o direito à vida e à incolumidade física e, finalmente, no Art. 2 II 2 GG (c.c. Art. 104 GG), o direito à liberdade (de locomoção) da pessoa, que impõe limites também ao eventual estado carcerário em que se encontre seu titular" (Cf. Leonardo Martins . Introdução à jurisprudência do Tribunal Constitucional Federal Alemão. Cinqüenta anos de jurisprudência do Tribunal Constitucional Federal Alemão. Organização e introdução: Leonardo Martins ; Trad. Beatriz Henning et al. . Prefácio: Jan Woischnik . Coletânea Original de Jürgen Schwabe . Montevidéu : Fundação Konrad Adenauer, 2005. p. 90). 
negativo (não ameaçar a vida, a liberdade, a integridade física, a intimidade ${ }^{65}$ ou a honra dos indivíduos).

Uma segunda geração de direitos relativos à pessoa humana - tutelada pelo Direito Constitucional e pelo Direito Internacional Público - diz respeito aos direitos de igualdade, decorrentes da Constituição do México de 1917 e da Constituição Alemã de 1919 (também conhecida como a Constituição da República de Weimar), na qual são tutelados direitos sociais como o dos trabalhadores e também o direito à igualdade entre os sexos (mais recentemente, merecendo destaque, em tal aspecto, a Lei Fundamental alemão de 1949) e também a igualdade racial. ${ }^{66}$

65 Complementando o que já colocamos em nota de rodapé anterior quanto ao direito de estar só e à análise de Celso Lafer quanto ao pensamento de Hannah Arendt a respeito da tutela da intimidade, : "Como para Hannah Arendt o público é o comum, que deve ser visivel, e o privado é o que diz respeito ao individuo na sua singularidade, e que deve, por isso mesmo, ficar com base no princípio da exclusividade, a tutela da intimidade é legítima com base no princípio da exclusividade. Esta defesa da intimidade, cuja importância a situação-limite da ruptura totalitária evidenciou pela desolação, Hannah Arendt examina de acordo com a sua metodologia, que resulta, conforme foi visto, de uma combinação de fenomenologia, ontologia, e hermenêutica. Para ela, a defesa da intimidade também se coloca como necessidade para a defesa da esfera pública, que se vê afetada quando o íntimo, cuja transparência deve ficar adstrita ao reservado, invade o público, pois esta invasão banaliza o público e compromete o juízo. É, portanto, igualmente na perspectiva do público que Hannah Arendt examina a intimidade, cuja publicização, assim como a privatização do público pelo social, na sua visão, não é adequada para a proposta de reconstrução do político, necessária, para se evitar um novo 'estado totalitário de natureza'. As colocações de Hannah Arendt e o próprio princípio de exclusividade do intimo, enquanto standard para limitar o direito de informação, ainda que extremamente interessante na sua formulação, estão sujeitos, como sempre, à tutela dos direitos humanos que não são apenas complementares mas conflitivos, à dificuldade de aplicação. Requerem sempre um juizo, que é o que para Kant, na leitura de Hannah Arendt, une a teoria à prática" (Cf. Celso Lafer . A reconstrução dos Direitos Humanos : um diálogo com o pensamento de Hannah Arendt. São Paulo : Companhia das Letras, 1988. p. 271)

${ }_{66}$ Embora o panorama tenha mudado, com a adoção do sistema de cotas em universidades públicas, o atual Ministro do Supremo Tribunal Federal Joaquim Benedito Barbosa Gomes, publicou em 2001, uma obra intitulada "Ação afirmativa \& Princípio constitucional da igualdade : o Direito como instrumento de transformação social: a experiência dos EUA" (Rio de Janeiro : Renovar, 2001), na qual afirmava que "na órbita jurídica interna, além dos dispositivos constitucionais genéricos que proíbem a discriminação racial e criminalizam certos comportamentos discriminatórios, o Direito brasileiro se singulariza pela esdrúxula estratégia de pretender extinguir a discriminação racial e seus efeitos mediante leis de conteúdo criminal (Lei n. 7.716/89 e Lei n. 9.459/97). Ineficazes, tais leis são muitas vezes objeto de deboche por parte de alguns operadores do Direito aos quais incumbiria aplicá-las. Não se tem notícia de um único caso de cumprimento de pena por condenação criminal fundada nessas leis. Já naquilo que é o essencial, e que constitui uma real garantia do exercício da cidadania, o Estado brasileiro é omisso. Com efeito, o país jamais cogitou de editar mediadas de cunho 'promocional', 'integrativo', suscetiveis de inserir os negros em igualdade de condições no mercado de trabalho e propiciar-lhes acesso à boa educação. O resultado disso éo 'apartheid informal 'que todos vêem mas parecem recusar-se a enxergar" (nota de rodapé $\mathrm{n}^{\circ} 13-\mathrm{p}$. 12-13) e que "concebidas pioneiramente pelo Direito dos Estados Unidos da América, as ações afirmativas consistem em políticas públicas (e também privadas) voltadas à concretização do princípio constitucional da igualdade material e à neutralização dos efeitos da discriminação racial, de gênero, de idade, de origem nacional e de compleição fisica. Impostas ou sugeridas pelo Estado, por seus entes vinculados e até mesmo por entidades puramente privadas, elas visam a combater não somente as manifestações flagrantes de discriminação, mas também a discriminação de fundo cultural, estrutural, enraizada na sociedade" (p. 6) 
A terceira geração seria a de direitos de solidariedade, em que a constatação de que partilhamos um destino comum exige um esforço em prol da tutela de um objeto mais amplo, como o meio ambiente ou a segurança no mercado de consumo, surgindo aí os interesses transindividuais (difusos, coletivos e individuais homogêneos) tão em voga na atualidade.

Há quem constate até o surgimento de uma nova geração de direitos humanos, os chamados "direitos de quarta geração" que poderiam ser resumidos, como ensinou Ricardo Lorenzetti, na expressão "direito a ser diferente", na qual, mesmo constituindo ainda "derivações da liberdade" seriam aplicações em "um campo em que, tradicionalmente, reinou o público, o homogêneo, e que se considerou vital para o funcionamento social", mas tais direitos "supõem um comportamento distinto ao dos demais individuos, por isso podem ser englobados" sob tal expressão ${ }^{67}$.

A positivação de direitos "de primeira, segunda e terceira geração, não elimina, e por vezes exacerba, os problemas práticos de sua tutela", como asseverou Celso Lafer ${ }^{68}$.

Cumpre aqui destacar as inúmeras críticas dirigidas ao termo "gerações de direitos", seja por Jorge Miranda, no sentido de transmitir a impressão de que uma primeira geração poderia ser substituída por outra ${ }^{69}$, como por José Joaquim Gomes Canotilho que prefere chamá-las de "dimensões" ao invés de "gerações"70, assim como por Antônio Cançado Trindade ${ }^{71}$ que, entre muitas outras críticas, endossa a de Jorge Miranda (no

${ }_{67}$ "Trata-se de questões tais como o direito à homossexualidade, à troca de sexo, ao aborto, a recusar tratamentos médicos que levem à morte" (Cf. Ricardo Luis Lorenzetti . Fundamentos do direito privado. Tradução de Vera Maria Jacob de Fradera . São Paulo : Revista dos Tribunais, 1998 . p. 154-155)

68 Exemplificando com "o direito à intimidade, que frequentemente se choca com o direito à informação e com a prática dele derivada do jornalismo de investigação, que tem sido considerado um ingrediente importante da liberdade de imprensa" (Cf. Celso Lafer . A reconstrução dos Direitos Humanos : um diálogo com o pensamento de Hannah Arendt. São Paulo : Companhia das Letras, 1988. p. 241)

69 O uso do vocábulo "geração" de direitos é, inegavelmente, impróprio, pois indica uma sequência de categorias de direitos, uma sucessão, na qual há a substituição de uma pela outra (Cf. Jorge Miranda . Teoria do Estado e da Constituição . Rio de Janeiro : Forense, 2002 . p. 24)

70 Assim teríamos, de acordo com José Gomes Canotilho, não uma terceira geração, mas sim uma terceira dimensão de "direitos sociais e dos trabalhadores" e uma quarta dimensão de "direitos dos povos". (Cf. José Joaquim Gomes Canotilho . Direito Constitucional . 6. ed. . Coimbra: Almedina, 2002 . p. 386)

71 "Quais são as razões de ordem jurídica que me fazem rechaçar essa tese nos meus livros e nos meus votos? Inclusive, citei aqui no caso dos meninos de rua, é um rechaço à tese de gerações de direitos, porque creio que o próprio direito fundamental à vida é de primeira, segunda, terceira e de todas as gerações. É civil, político, econômico-social e cultural. Em primeiro lugar, essa tese não corresponde à verdade histórica. É certo que houve as declarações dos séculos XVII e XVIII e a Revolução Francesa, e parece-me que a doutrina brasileira parou por aí. Houve a revolução americana e depois a Declaração Universal. Essa conceituação de que primeiro vieram os direitos individuais e. nesta ordem, os direitos econômicosociais e o direito de coletividade correspondem à evolução do direito constitucional. É verdade que isso ocorreu no plano dos direitos internos dos países, mas no plano internacional a evolução foi contrária. No plano internacional, os direitos que apareceram primeiro foram os econômicos e os sociais. As primeiras convenções da OIT, anteriores às Nações Unidas, surgiram nos anos 20 e 30. O direito ao trabalho o direito 
sentido de que uma geração de direitos pode ser substituída por outra), bem como defende a concepção de que o direito à vida deve permanecer em todas as gerações de direitos.

\begin{abstract}
às condições de trabalho é a primeira geração, do ponto de vista do Direito Internacional. A segunda geração corresponde aos direitos individuais, com a Declaração Universal e a Americana, de 1948. Então, a expressão 'gerações' é falaciosa, porque não corresponde ao descompasso, que se pode comprova; entre o direito interno e o direito internacional em matéria de direitos humanos. Esta é a primeira razão histórica. Trata-se de construção vazia de sentido e que não corresponde à realidade histórica. Segundo, é uma construção perigosa, porque faz analogia com o conceito de gerações. O referido conceito se refere praticamente a gerações de seres humanos que se sucedem no tempo. Desaparece uma geração, vem outra geração e assim sucessivamente. Na minha concepção, quando surge um novo direito, os direitos anteriores não desaparecem. Há um processo de cumulação e de expansão do corpus juris dos direitos humanos. Os direitos se ampliam, e os novos direitos enriquecem os direitos anteriores. Do ponto de vista jurídico, a teoria das gerações de direitos não tem nenhum fundamento. Vou dar dois exemplos práticos, concretos, sobre os perigos da teoria das gerações de direitos. Primeiro, a concepção que prevalece no mundo ocidental e sobretudo ao norte do Equador, na América do Norte, onde, para a maioria das pessoas, os direitos humanos são sinônimos de civil rights e os direitos econômico-sociais seriam puramente programáticos, o que ainda é a visão que prevalece em países como Estados Unidos e Canadá, como todos sabemos. For outro lado, há a visão que prevalece no extremo oriente. Tive oportunidade de visitar a China duas vezes, através do Comitê Internacional da Cruz Vermelha. Na segunda visita, estive com um juiz da Corte Européia. Foram dois convidados: um do sistema interamericano e um do sistema europeu. Acompanhou-me um juiz da Dinamarca, St Foighel. O tema de que tratamos foi 'O devido processo legal'. O Juiz Foighel, da Corte Européia, falou sobre a jurisprudência em matéria de devido processo legal na Europa, e eu falei sobre a jurisprudência incipiente interamericana. Os chineses nos escutavam um tanto atônitos e diziam: 'Aqui damos um fair trail and then we hang everybody'. Eles não têm essa mesma noção de direitos de devido processo que, na verdade, permeia os direitos civis e políticos e os direitos econômicos, sociais e culturais. Essa concepção tem causado grande dano à evolução dos direitos humanos. Por exemplo, por que razão a discriminação é combatida e criticada somente em relação aos direitos civis e politicos e é tolerada como inevitável em relação aos direitos econômicos, sociais e culturais? Porque são supostamente de segunda geração e de realização progressiva. Então, vemos uma condenação absoluta de qualquer tipo de discriminação quando se trata de direito individual ou mesmo de direitos políticos mas uma tolerância absoluta quando se trata de disparidades em matéria de salário, de renda, e assim por diante. Em vez de ajudar a combater essa visão atomizada, essa teoria de geração de direitos convalida esse tipo de disparidade. Estava mencionando que, no caso da China, para os chineses, ao contrário dos americanos do Norte, os verdadeiros direitos são os econômicos e sociais, Os direitos civis e políticos, os direitos ao devido processo ficam para o século XXI ou para o século XXII. Da mesma maneira, na América Latina é o contrário. Os direitos econômicos e sociais vão deixar o bolo crescer, como já se dizia na época da ditadura, e depois quem sabe no futuro vamos dividi-lo. Vejam os perigos dessa teoria. Para mim, o testemunho mais eloqüente da falta de fundamento dessa teoria são essas distorções que verificamos em diferentes partes do mundo e que requerem a visão da indivisibilidade e inter-relação entre todos os direitos humanos" (Cançado Trindade Questiona a Tese de "Gerações de Direitos Humanos" de Norberto Bobbio. DHNet - Direitos Humanos na Internet. Disponível em: <http://www.dhnet.org.br/direitos/militantes/ cancadotrindade/cancado_bob.htm>. Acesso em: 15 set. 2007.).
\end{abstract}


O mais importante, incontestavelmente, e esse é um denominador comum em relação aos direitos fundamentais, aos direitos humanos e aos direitos da personalidade é sua efetivação, ${ }^{72} \mathrm{o}$ que pode ocorrer por quaisquer normas presentes no sistema. ${ }^{73}$

Como uma disciplina em constante mutação, é neste ponto que reconhecemos que diversos exemplos e simplificações conceituais utilizadas no estudo dos direitos da personalidade - ainda que úteis didaticamente em um primeiro contato com o tema - nem sempre resistem à necessidade de aprofundamento e à crescente complexidade da matéria.

Em semelhante sentido, observou Silmara Juny de Abreu Chinellato, em razão de suas pesquisas relacionadas à vida humana em geral e ao nascituro em particular, o tratamento jurídico dado aos embriões ${ }^{74}$ denota e denotará a necessidade de que os direitos da personalidade jamais sejam normatizados em rol taxativo (o que - é imperativo constatar - iria contra sua própria natureza jurídica, fundada no Direito Natural).

Ainda que os direitos da personalidade possam ser previstos em um diploma legal oriundo de um Estado autoritário (o Código Civil de 1942, ainda no período do Ditador italiano Benito Mussolini, constitui um exemplo muito adequado), é somente no Estado Democrático de Direito que os direitos da personalidade poderão encontrar sua real dimensão.

É muito conhecida a passagem em que Adriano De Cupis, jurista italiano especializado no estudo dos direitos da personalidade, ofereceu ao "Duce" sua obra para que esta não fosse censurada (no que foi muito hábil, até porque a obra defendia, entre outros direitos, o direito à liberdade), mas é seguramente apropriado que o nascedouro das normas jurídicas que versem sobre tema tão essencial seja a plena democracia.

72 Norberto Bobbio sintetiza a imperatividade da efetivação de tais direitos de forma clara e objetiva, ao afirmar que "o problema que temos diante de nós não é filosófico, mas jurídico e, num sentido mais amplo, político. Não se trata de saber quais e quantos são esses direitos, qual é sua natureza e seu fundamento, se são direitos naturais ou históricos, absolutos ou relativos, mas sim qual é o modo mais seguro para garantilos, para impedir que, apesar das solenes declarações eles sejam continuamente violados" (Cf. Norberto Bobbio. A era dos direitos. Tradução de Carlos Nelson Coutinho. 9. ed. Rio de Janeiro : Elsevier, 2004. p. 45.)

73 Este não é um problema que ocorre apenas no ordenamento jurídico brasileiro, uma vez que António Menezes Cordeiro relatou, quanto ao que ocorre em Portugal, que "o Código Civil - e foi pena - não isolou os diversos direitos de personalidade, de modo a referir o direito à integridade moral, ao bom nome e reputação. Subjacente está o direito à honra, de largas tradições no Ocidente. O art. 70.\% limita-se a proteger: (...) os indivíduos contra qualquer ofensa ilicita ou ameaça de ofensa à sua personalidade (...) moral. Mas a Constituição ao seriar entre os direitos fundamentais, no seu artigo 26. ${ }^{\circ}$, o direito ao bom nome e reputação, dá uma base jurídico-positiva sobeja, a este direito muito importante, nos dias de hoje" e "por seu turno, o Código Penal compreende, nos seus artigos $180^{\circ}$ e seguintes, um capitulo com crimes contra a honra" (Cf. António Menezes Cordeiro . Tratado de Direito Civil Português: Direito das Obrigações. v. II . t. III . p. 551-552)

74 No mesmo sentido, Norberto Bobbio advertiu para os riscos que envolvem e envolverão a pesquisa biológica, com o risco da manipulação do patrimônio genético de cada indivíduo e indaga o autor: quais seriam os limites de tal manipulação ? (Cf. Norberto Bobbio . A era dos direitos. Tradução de Carlos Nelson Coutinho . 9. ed. . Rio de Janeiro : Elsevier, 2004 . p. 6) 
Goffredo Telles Júnior, magistralmente, enfatizava que o Direito constitui a disciplina da convivência, ${ }^{75}$ em que a liberdade desempenha um papel fundamental, só possível na plena democracia.

Tão intuitiva quanto a necessidade de liberdade humana é que os fundamentos morais do exercício da liberdade devem sempre coincidir com os fundamentos jurídicos.

\section{Características}

Em uma elaborada síntese quanto às características dos direitos da personalidade em diversos autores, Fábio Maria De Mattia apresentou: irrenunciabilidade;

1) Adriano De Cupis - intransmissibilidade, indisponibilidade, e

2) Jean Carbonnier - geral (por atingir a todas as pessoas), extrapatrimonial e absoluto;

3) Alberto Trabucchi - não patrimonial, absoluto, inalienável, intransmissível, imprescritível e irrenunciável;

4) Arturo Valencia Zea - absoluto, inato, fora do comércio e insuscetível de avaliação patrimonial. $^{76}$

Infelizmente, muito do que é defendido doutrinariamente é ignorado pelo legislador e um caso emblemático é o que envolve a imprescritibilidade dos direitos da personalidade.

Se fossem seguidos os ensinamentos dos doutrinadores quanto à imprescritibilidade, a violação - por exemplo - do direito à honra, possibilitaria que, a qualquer tempo, fosse exercida a pretensão que visa o ressarcimento do dano, o que já não ocorria no Código Civil anterior (com prazo de vinte anos para o exercício da pretensão) e, menos ainda, no Código Civil em vigor (no qual houve drástica redução do prazo para três anos).

Não bastasse isso, o art. 11 do Código Civil de 2002 estabelece que "com exceção dos casos previstos em lei, os direitos da personalidade são intransmissíveis e irrenunciáveis, não podendo o seu exercício sofrer limitação voluntária", destacando assim a intransmissibilidade 77 e irrenunciabilidade dos direitos da personalidade.

75 Cf. Goffredo Telles Júnior . Iniciação na Ciência do Direito . São Paulo : Saraiva, 2001 . p. 381

76 Cf. Fábio Maria De Mattia . Direitos da personalidade : aspectos gerais . Estudos de Direito Civil . Antônio Chaves (coord.). São Paulo : Revista dos Tribunais, 1979 .p. 110-111.

77 De acordo com Gilberto Haddad Jabur ocorre uma limitação quanto à disposição (no que tange ao exercício de direitos) em decorrência das diversas exigências da vida contemporânea, visando com isso um equilíbrio entre a proteção à pessoa e a liberdade no exercício dos direitos (Cf. Gilberto Haddad Jabur . Liberdade de pensamento e direito à vida privada: conflitos entre direitos da personalidade. São Paulo: Revista dos Tribunais, 2000 . p. 55-56.) 
Todavia, como adverte Renan Lotufo, "ainda que o texto do art. 11 pareça ficar restrito à intransmissibilidade e irrenunciabilidade, parece claro que o conjunto de disposições também contempla os demais caracteres dados como inerentes aos direitos da personalidade, como do absolutismo, da generalidade, necessariedade e vitaliciedade". ${ }^{78}$

No mesmo sentido, Silmara Chinellato afirma que "além das características mencionadas no artigo, os direitos da personalidade são, ainda, inalienáveis, imprescritíveis e impenhoráveis", acrescentando que "o exercício de alguns direitos, como o direito à imagem (reprodução física da pessoa, no todo ou em parte) e à voz, pode ser cedido, por contrato expresso, como o de licença de uso", mas "o próprio direito é incessível, como decorrência da inalienabilidade". ${ }^{79}$

Existem características comuns ao direito geral de personalidade (que abordaremos na parte final deste trabalho) e aos direitos da personalidade, como ensinou Antonio Junqueira de Azevedo, para quem "são características do direito geral de personalidade: inalienabilidade, incessibilidade, imprescritibilidade, impenhorabilidade, intransmissibilidade" lembrando que, "em regra, essas características também são dadas como próprias dos direitos, no plural, de personalidade; elas estão, em parte, expressas no artigo 11 do atual Código Civil". ${ }^{80}$

\section{Classificação}

No que diz respeito à classificação dos direitos da personalidade, podemos visualizar classificações diversas, assumindo relevo a classificação bipartida (direito à integridade física e direito à integridade moral ${ }^{81}$ ) de Orlando Gomes e as classificações

78 "O absolutismo decorre do fato de ser logicamente oponível erga omnes, impondo-se à coletividade o dever de respeitá-los. A generalidade, que consiste em ser concedida a todos, pelo simples fato do ser humano estar vivo, de ser, implica a existência e investidura dos direitos da personalidade. A extrapatrimonialidade, que decorre da indisponibilidade expressa na intransmissibilidade, ademais, é vista como característica desses direitos por serem insuscetíveis de avaliação econômica, mesmo que sua lesão gere efeitos econômicos. Conseqüencia de serem indisponíveis é serem irrenunciáveis e impenhoráveis" (Cf. Renan Lotufo . Código Civil Comentado : parte geral (arts. $1^{\circ}$ a 232). v. 1 . São Paulo : Saraiva, 2003. p. 53)

79 "Em regra, o exercício dos direitos não pode sofrer limitação voluntária pelo próprio titular. Essa é a regra que comporta exceções: como a referente ao direito à imagem, à voz, ao nome, ao corpo. Diante da regra, com maior razão o exercício dos direitos da personalidade não poderá sofrer limitação involuntária, por ato de terceiros, considerando-se que uma de suas características é ser 'personalíssimo', pertencente, com exclusividade, ao próprio titular. Assim, só se admite o exercício por terceiros de alguns direitos da personalidade, que o comportem, com o consentimento expresso do titular, o qual não se presume" (Cf. Silmara Juny de Abreu Chinellato . Comentários à Parte Geral - artigos $1^{\circ}$ a 21 do Código Civil. In: Antonio Cláudio da Costa Machado. (Org.) Silmara Juny Chinellato (Coord.) . Código Civil Interpretado : artigo por artigo, parágrafo por parágrafo. $5^{\mathrm{a}}$ ed. . Barueri : Manole, 2012 . p. 42).

80 Cf. Antonio Junqueira de Azevedo . Novos estudos e pareceres de Direito Privado . São Paulo : Saraiva, 2009. p. 485

81 Ensinava Orlando Gomes que são "direitos à integridade física: a) o direito à vida; b) o direito sobre o próprio corpo. O direito sobre o próprio corpo subdivide-se em direito sobre o corpo inteiro e direito sobre 
tripartidas de Carlos Alberto Bittar (integridade física, psíquica e moral ${ }^{82}$ ) e de Rubens Limongi França (intelectual, física e moral), sem olvidar da classificação de Silmara Juny de Abreu Chinelato e Almeida que propõe que o direito à vida deve ficar como espécie à parte, pois dele decorrem os demais direitos da personalidade. ${ }^{83}$

6. Início da vida e defesa dos direitos da personalidade após a morte

O fato da vida - e da própria personalidade como aptidão para figurar em uma relação jurídica - constituir o suporte dos direitos da personalidade, não impede que tais direitos sejam defendidos após a morte de seu titular.

Como ponderou Silmara Juny de Abreu Chinellato (Código Civil comentado artigo por artigo, parágrafo por parágrafo), não é aplicável o “mors omnia solvit" (a morte resolve tudo), sendo possível identificar no art. 12, parágrafo único da Lei 10.406/02 (Código Civil em vigor) a legitimação de parentes em linha reta e de colaterais até o quarto grau para pleitear perdas e danos causados ao morto.

partes separadas, compreendendo os direitos de decisão individual sobre tratamento médico e cirúrgico, exame médico e perícia médica. Admitem-se como direitos à integridade moral: a) o direito à honra; b) o direito à liberdade: c) o direito ao recato; d) o direito à imagem; e) o direito ao nome; f) o direito moral do autor" (Cf. Orlando Gomes . Introdução ao Direito Civil . 14 a ed. . atualização e notas de Humberto Theodoro Júnior . Rio de Janeiro : Forense, 1999 . p. 153)

82 Ao apresentar sua classificação em direitos físicos, psíquicos e morais, Carlos Alberto Bittar explicou que "nessa classificação toma-se, de início, a pessoa como ser individual, destacando-se seus dotes físicos, ou atributos naturais em sua composição corpórea (ou conformação física). São os elementos extrínsecos da personalidade. Ao depois, volvendo-se para o seu interior, encontram-se os direitos psíquicos, ou atributos da inteligência ou do sentimento. São os elementos intrínsecos ou íntimos da personalidade (que compõem o psiquismo humano). De outro lado, à vista da consideração da pessoa como ser social, localizam-se os direitos morais, correspondentes a qualidades da pessoa em razão da valoração na sociedade, frente a projeções ou a emanações (ou manifestações) em seu contexto (...) Em consonância com as noções expostas, incluímos, dentre os direitos físicos, os seguintes direitos: à vida, à integridade física (higidez corpórea); ao corpo; a partes do corpo (próprio e alheio); ao cadáver e a partes; à imagem (efígie) e à voz (emanação natural). Dentre os psíquicos, inserimos os direitos: à liberdade (de pensamento, de expressão, de culto e outros); à intimidade (estar só, privacidade, ou reserva); à integridade psíquica (incolumidade da mente); a segredo (ou sigilo, inclusive profissional). Dentre os de cunho moral, colocamos os direitos: à identidade (nome e outros sinais individualizadores); à honra (reputação, ou consideração social), compreendendo a externa, ou objetiva: boa fama, ou prestígio; e a interna, ou subjetiva: sentimento individual ou do próprio valor social; ao respeito (conceito pessoal, compreendendo a dignidade: sentimento das próprias qualidades morais; e o decoro: a conceituação da própria respeitabilidade social); às criações intelectuais (produtos do intelecto, sob o aspecto pessoal do vínculo entre o autor e a obra, incluída a correspondência)" (Cf. Carlos Alberto Bittar . Os direitos da personalidade. Rio de Janeiro : Forense Universitária, 1989 . p. 63-64).

83 "Consideramos, destarte, a seguinte divisão quadripartite: direito à vida, direito à integridade física, direito à integridade moral e direito à integridade intelectual", pois "divergindo apenas em parte - e não em substância da classificação tripartite dada por R. Limongi França” aos direitos da personalidade, "classificamo-los em quatro categorias fundamentais, colocando o direito à vida como categoria autônoma do direito à integridade fisica, por ser um direito condicionante, do qual dependem todos os demais" (Cf. Silmara Juny de Abreu Chinelato e Almeida . Tutela civil do nascituro. São Paulo : Saraiva, 2.000 . p. 292293). 
Exemplos significativos ocorreram (de violação à honra e imagem, que não se confundem como destaca Cláudio Luiz Bueno de Godoy ${ }^{84}$ ), como a filmagem de Di Cavalcanti em seu velório - de forma pouco respeitosa - efetuada por Glauber Rocha ${ }^{85}$ para

84 Cláudio Luiz Bueno de Godoy pondera que "a elasticidade do conceito de direito à imagem presta-se sobremaneira a fomentar a confusão que dele se faz com o direito à honra. A ponto, inclusive, de se sustentar, tal como lembra Pontes de Miranda, que a imagem de alguém é protegida como decorrência de simultânea ofensa a sua honra e, portanto, não chega mesmo a constituir um autônomo direito da personalidade", mas conclui que "em verdade, porém, imagem e honra não se confundem. Tanto assim que o direito à imagem pode ser violado sem que seja afetada a honra de uma pessoa" (Cf. Cláudio Luiz Bueno de Godoy . A liberdade de imprensa e os direitos da personalidade . $2^{\mathrm{a}}$ ed. . São Paulo : Atlas, 2008 .p. 36). Usa para tanto a obra de Pedro Frederico Caldas, na qual este diz que "prefigure-se o fato de uma pessoa famosa (grande artista, excepcional desportista ou notável intelectual) conceder que uma agência encarregada utilize sua imagem em uma campanha de grande interesse público. Suponha-se que a imagem foi utilizada corretamente segundo os fins propostos: nada de mais; suponha-se que a agência aproveitou a imagem captada e a utilizou em publicidade comercial a cargo de sua agência: violação do direito à imagem; suponha-se, ainda, que o reclame comercial prestigiasse determinada bebida alcoólica e que a celebridade pertencesse notoriamente a uma seita ferrenhamente contrária ao uso do álcool: violação da imagem e da honra. O exemplo, hipotético embora, bem demonstra que a utilização da imagem de alguém pode ser feita como exercício regular do direito (houve consentimento), pode ser feita contrariamente ao direito à imagem, e pode ser feita com simultânea lesão ao direito á imagem e ao direito à honra" (Cf. Pedro Frederico Caldas . Vida privada, liberdade de imprensa e dano moral . São Paulo : Saraiva, 1997. p. 35).

85 "É curiosa a história de Di Glauber. O curta documentário foi rodado durante o enterro de Di Cavalcanti, em outubro de 1976, no Rio. No ano seguinte, recebeu o prêmio especial do júri no Festival de Cannes. Embora curto, na duração, Di Glauber é uma das obras maiores de Glauber, à altura de Deus e o Diabo na Terra do Sol e Terra em Transe, fornecendo uma súmula do seu pensamento muito mais contundente do que o longa Idade da Terra, de 1980. Com fotografia de Mário Carneiro, Di Glauber focaliza o ambiente do velório e, depois, o enterro. A cena que mais desagrada à família é aquela em que Glauber levanta o véu que cobre o rosto do morto e grita para o operador de câmera que filme ali (...)(...) José Mauro Gnaspini faz hoje na Escola de Comunicações e Artes da Universidade São Paulo uma defesa de tese que vai dar o que falar. Formado em Direito na faculdade do Largo São Francisco, ele resolveu se especializar em direito autoral e de imagem. E foi buscar na ECA-USP as condições e o orientador (Rubens Machado) para a tese de mestrado que defende hoje, em audiência pública, a partir das 10 horas. Com o sugestivo título de Di Glauber - O Filme como Funeral Reprodutivel, Gnaspini não vai apenas analisar a obra de Glauber Rocha à luz da estética. O que torna sua tese particularmente interessante é o fato de o autor haver descoberto falhas no processo que levou à interdição do curta Di Glauber, a pedido da filha do pintor Emiliano Di Cavalcanti, Elizabeth. Na verdade, o que ele vai provar é que não existem fundamentos jurídicos para essa interdição e, portanto, o filme de Glauber pode ser liberado, imediatamente, para exibições - a menos que a família inicie outro processo. O de número 99.111, de 1979, apresentado na 6. ${ }^{a}$ Vara Cível do Rio de Janeiro, não sustenta a proibição. Não é a primeira vez que Glauber vira tema de tese polêmica. Em dezembro de 1993, o jornalista e crítico de cinema Júlio Lobo apresentou na Universidade Federal da Bahia outra tese de mestrado, intitulada Muito Romântico (Poesia e Política no Filme Terra em Transe). Sua tese privilegiava a discussão sobre o engajamento político do intelectual. Tentava provar que a arte não pode nem deve estar a reboque da politica. A tese de Gnaspini agora é outra. Sob a orientação de Rubens Machado, ele analisou detalhadamente a obra de arte glauberiana para polemizar sobre os conceitos de desrespeito e sensacionalismo invocados pela família de Di para pedir (e obter) a interdição, em juizo, do curta-metragem que não pode ter exibições públicas no País - mas, curiosamente, já passou em retrospectivas dedicadas a Glauber no exterior. A idéia central da tese de Gnaspini é que Glauber criou, na tela, uma espécie de funeral alternativo, cujo cerimonial se repetiria cada vez em que of filme fosse projetado. Em busca de base jurídica para a tese que pretendia desenvolver, a primeira coisa que Gnaspini fez foi procurar uma cópia do processo no Arquivo Público do Rio de Janeiro. Estarrecido, descobriu que a cópia que lá deveria estar depositada sumiu. Só conseguiu restitui-la por meio de fragmentos recolhidos em diferentes escritórios de advocacia que, ao longo dos anos, têm tratado do assunto" (Uma tese polêmica 
o filme $\mathrm{Di}^{86}$, sendo tal exemplo mencionado por Regina Sahm em obra específica sobre direito à imagem ${ }^{87} \mathrm{e}$, ironicamente, do próprio Glauber Rocha em seu velório ${ }^{88}$ quando Silvio Tendler realizou a obra "Glauber o filme, labirinto do Brasil".

O momento da morte também é importante por possibilitar a doação de órgãos únicos após a morte (questão regulada pela Lei 9.434/97 que, em seu art. $3^{\circ}$,

sobre Glauber. José Mauro Gnaspini defende hoje na ECA- USP dissertação que pode liberar 'Di Glauber'. Luiz Carlos Merten . Quinta-feira, 4 de setembro de 2003 . Disponível em <http://www.estado. estadao.com.br/editorias/2003/09/04/cad033.html> . Acesso em 21 mar. 2004).

86 Conhecido posteriormente como "Di Glauber", alguns dados interessantes constam no site Adoro Cinema Brasileiro que informou que em 1977 "Glauber Rocha finalizou seu filme, e no ano seguinte foi premiado no Festival de Cannes, cujo júri era presidido pelo cineasta Roberto Rosselini, amigo de Di Cavalcanti. / A exibição do filme foi interditada pela justiça desde 1979, quando da conceção de liminar pela 7a. Vara Civel, ao mandado de segurança impetrado pela filha do pintor, Elizabeth Di Cavalcanti. / De acordo com uma reportagem publicada no jornal O Globo do dia 12 de junho de 1979, dia seguinte à proibição, Di chegou a passar nas sessões das $14 \mathrm{~h}$ e $16 \mathrm{~h}$ em alguns cinemas da cidade. Mas às 18h, o oficial de Justiça Walter Coelho Fanti e o advogado de Elizabeth Di Cavalcanti, Eduardo Mattar, chegaram ao cinema Rio Sul, onde haveria projeção com a presença de Glauber e convidados. As latas com o filme foram lacradas e recolhidas ao Museu da Imagem e do Som. / Chegou a ser exibido duas vezes na televisão, na TVE do Rio, antes de sua proibição, e na Bandeirantes, num especial sobre o diretor, que foi ao ar depois de sua morte / Mais de 20 anos depois de ter sua exibição proibida através de uma liminar, o filme pode voltar a ser exibido. Não porque tenha sido liberado, enfim, pela Justiça. Mas simplesmente porque nunca esteve legalmente impedido. O advogado José Mauro Gnaspini defendeu uma tese de mestrado sobre direito autoral na Escola de Comunicação e Artes da Universidade de São Paulo. Segundo Gnaspini - que reconstituiu a ação a partir de fragmentos espalhados por escritórios de advocacia do Rio, pois o processo havia desaparecido do Arquivo Público da cidade - não existem fundamentos jurídicos para a interdição e o filme pode ser liberado, imediatamente, para exibições. / O filme nunca chegou realmente a ser proibido. A ação ocorreu só contra a Embrafilme. Glauber, que tinha direito inalienável sobre a obra, não sofreu um processo" (Disponível em <http://www.adorocinemabrasileiro.com.br/curtas/di/di.asp> . Acesso em: 21 mar. 2004).

87 "Violação de direito à imagem de pessoa falecida, no sentido imagem-retrato, ocorreu na captação da imagem mortuária do pintor Di Cavalcanti quando exposta no Museu de Arte Moderna do Rio de Janeiro. A obra cinematográfica de autoria de Glauber Rocha permanece inédita por decisão judicial que decidiu pela interdição, a pedido dos herdeiros do famoso pintor" (Cf. Regina Sahm . Direito à imagem no Direito Civil contemporâneo : de acordo com o novo Código Civil - Lei no 10.406, de 10-1-2002. São Paulo : Atlas, 2002 . p. 241)

88 "Quando Glauber Rocha morreu, em 1981, o cineasta Silvio Tendler registrou o velório e o enterro do diretor. Ele repetia assim o próprio Glauber, que, em 1976, filmou o velório de Di Cavalcanti. O filme de Glauber sobre o pintor ganhou prêmio especial no Festival de Cannes, mas está até hoje proibido no Brasil por uma decisão da filha de Di, Elizabeth Cavalcanti. Ironicamente, as imagens de Glauber também foram interditadas por ordem da mãe do cineasta, dona Lúcia Rocha. Somente em 1999, 18 anos depois, ela permitiu o uso das cenas. Tendler pegou o material interditado, fez entrevistas com amigos do diretor, recolheu imagens de arquivo e lança na sexta-feira - 23 anos depois - "Glauber o filme, labirinto do Brasil", que ganhou os prêmios do júri popular e da crítica no último Festival de Brasília" (Reportagem sobre "Glauber o filme, labirinto do Brasil". Quinta-feira, Março 04, 2004 . MAURO VENTURA . Disponível em: <http://www.dizventura2.blogger.com.br/> . Acesso em: 21 mar. 2004) 
considera a morte encefálica ${ }^{89}$ como o fim da vida ${ }^{90}$ ), ainda que seja possível a doação de órgãos duplos em vida.

A esse respeito, José Carlos Moreira Alves, autor da Parte Geral do Código Civil em vigor, observou que - ao contrário do anteprojeto de Orlando Gomes - o art. 15 do Código Civil atual possibilitou a autorização para o transplante, mesmo que este importe em diminuição permanente, repetindo o que já havia sido previsto pelo art. $10, \S$ $2^{\circ}$ da Lei 5.479/68 que versava sobre transplante de rins ${ }^{91}$.

Já que analisamos o momento em que a existência física da pessoa termina, cabe indagar sobre seu início. Clóvis Bevilaqua inseriu no Código Civil anterior uma condição de aquisição da personalidade : o "nascer com vida". O que justificaria a proteção desde a concepção seria a consideração pelo próprio feto, que vedava a aplicação de pena de morte a uma mulher grávida (que sequer era submetida a julgamento em tal situação) e, indagava Bevilaqua: se o Direito Penal apresentava tal consideração pelo feto, por que não o Direito Civil? ${ }^{92}$

$89 \quad$ Art. $3^{\circ}$ da Lei 9.434/97: “A retirada post mortem de tecidos, órgãos ou partes do corpo humano destinados a transplante ou tratamento deverá ser precedida de diagnóstico de morte encefálica, constatada e registrada por dois médicos não participantes das equipes de remoção e transplante, mediante a utilização de critérios clínicos e tecnológicos definidos por resolução do Conselho Federal de Medicina".

90 Antônio Chaves relatou que "a hoje aceita morte encefálica se distancia da morte cerebral, que tem sua verificação consistente em 'estabelecer, com minuciosos exames clínicos-neurológicos e pelo chamado teste de supressão ou teste de apnéia, respaldados por exame complementar que demonstre inequivocamente a ausência de atividade cerebral, ou de circulação sanguínea cerebral, a ocorrência de lesão irreversivel do encéfalo como um todo (...)" e citou Cláudio Cohen, que relatou que "o conceito de morte foi variando de parada irreversivel cardiopulmonar para morte cerebral, até o atual conceito de morte encefálica. Em 1968, a Universidade de Harvard estabeleceu novo critérios médicos para determinar a morte nos casos que foram considerados mais complexos, estabelecendo, desta maneira, os critérios para o diagnóstico de morte cerebral, relacionando-os da seguinte maneira: ausência de resposta a estímulos externos; ausência total de movimentos musculares e respiratórios; ausência de reflexos, especialmente o fotomotor e eletroencefalograma isoelétrico, sendo que todas essas investigações devem ser repetidas depois de 24 horas. Esta reavaliação após 24 horas demonstra a necessidade de uma reconfirmação do diagnóstico de morte, mostrando desta forma a falta de uma certeza absoluta da morte do indivíduo. A partir da Declaração de Sidney (1968), a assembléia da Associação Médica Mundial passou a considerar como morte, desde o ponto de vista médico, 'morte neurológica', abandonando-se o conceito de só se morre quando o coração pára" (Cf. Antônio Chaves. Direito à vida e ao próprio corpo : intersexualidade, transexualidade, transplantes . $2^{\mathrm{a}}$ ed. . São Paulo : Revista dos Tribunais, 1994. p. 50-52)

91 "O parágrafo único do art. 15 admite atos de disposição do próprio corpo ainda quando importem diminuição permanente da integridade física, se para fins de transplante, e na forma estabelecida em lei especial. O Projeto revisto e o Anteprojeto Orlando Gomes não faziam essa ressalva, como, aliás, ocorria com o art. $5^{\circ}$ do Código Civil italiano de 1942. Mas, como se deu na Itália - onde se derrogou esse art. $5^{\circ}$ pela Lei n. 458, de 1967, que admitiu o transplante de rim -, o mesmo se verifica no Brasil, em que a Lei n. 5.479, de 10 de agosto de 1968, em seu art. 10, § $2^{\circ}$, permite o transplante desse órgão" (Cf. José Carlos Moreira Alves . A Parte Geral do Projeto de Código Civil Brasileiro : subsídios históricos para o novo Código Civil brasileiro . $2^{\mathrm{a}}$ ed. . São Paulo : Saraiva, 2003 . p. 76)

92 "A personalidade civil do ser humano começa com a concepção, declarava o Projecto do Codigo Civil brasileiro elaborado em 1899, sob a condição, accrescentava, de nascer com vida. Esta doutrina apóia-se em razões valiosas, e tem por si autoridades egrégias. As razões são as seguintes: a) Desde a concepção o ser humano é protegido pelo direito. A provocação ao aborto é punida. Quando, entre nós, havia a pena 
$\mathrm{O}$ que parecia inovador e até revolucionário no início e até meados ${ }^{93}$ do século XX, deixou de o ser em pleno século XXI, no qual constatamos a possibilidade de vida fora do útero materno ${ }^{94} \mathrm{e}$ em que o otimismo da humanidade é compartilhado na mesma medida com o receio - em nada infundado - dos desdobramentos decorrentes de tecnologias que hoje sequer dominamos completamente.

O Direito passa por modificações sociais e, como salientou Edmond Picard (em sua obra Le Droit Pur), o Direito é um ideal armado de força, não prioritariamente agressivo, mas com escopo reparador e, com isso, voltado à realização de um efetivo ideal de justiça. ${ }^{95}$

de morte, não era applicada à mulher em estado de gravidez. Nesse estado não era sequer submetida a julgamento. O Direito penal mostra, assim, considerações pelo feto, isto é, por um ser humano ainda não desprendido das entranhas maternas. Por não faria o mesmo o Direito Civil ? Não podia deixar de attender ao ser humano nessa phase da existência" (Cf. Clóvis Bevilaqua . Theoria Geral do Direito Civil . 2 ${ }^{\mathrm{a}}$ ed. . Rio de Janeiro : Francisco Alves, 1929. p. 85)

93 Ainda em 1952 advertia José Castan Tobeñas: "En general, la humanidad, aun a trueque de tantas dificultades y tantos tropiezos como se le interponen em su camino, sigue una marcha progresiva en muchos aspectos. El sentido del respeto hacia la personalidad individual, em sus diversas manifestaciones, fisicas y espirituales, es hoy más vivo que en otras épocas, o cuando menos, alcanza um área más general de aplicación. Pero, a la vez, la vida moderna con su complejidad y sus progresos técnicos ha aumentado las ocasiones y los procedimientos de lesión de los atributos de la personalidad" (Cf. José Castan Tobeñas . Los derechos de la personalidad . Madri :Instituto Editorial Reus, 1952. p. 61-62).

94 A questão deixou de ser nova e encontra previsão no art. 1.597 do Código Civil em vigor, que determinou que presumem-se como concebidos na constância do casamento os filhos que “(...) III - havidos por fecundação artificial homóloga, mesmo que falecido o marido; IV - havidos, a qualquer tempo, quando se tratar de embriões excedentários, decorrentes de concepção artificial homóloga; $V$ - havidos por inseminação artificial heteróloga, desde que tenha prévia autorização do marido". Anteriormente à aprovação do Código Civil, advertia-se que haveria a necessidade de que "a legislação futura, civil e penal - na esteira da Lei alemão, de 03 de dezembro de 1990, que entrou em vigor em $1^{\circ}$ de janeiro de 1991 - proteja especialmente o pré-embrião, assim denominado o embrião ainda não implantado, isto é, enquanto 'in vitro' ou crioconservado. O pré-embrião, ou pré-nascituro, segundo terminologia por nós proposta - é uma pessoa 'in fieri', pois já dotado de carga genética própria, plenamente diferenciada quanto à do doador do sêmen e do óvulo. Cumpre observar que o direito constituendo poderá considerar como nascituro o pré-embrião. Esta é uma tendência que aplaudimos, mas, dadas suas peculiaridades, parece-nos deva ser objeto de previsão expressa consagrando a paridade entre embrião e pré-embrião, para que ambos se compreendam no conceito de nascituro que, destarte, teria sentido lato" (Cf. Silmara Juny de Abreu Chinelato e Almeida Direitos da personalidade do nascituro. Revista do Advogado. São Paulo. n. 38, 1992 . p. 21-22).

95 Para Edmond Picard "Or, si elle contraint celui qui viole un droit, du môme coup elle protège celui dont le droit est violé. Il y a là une répercussion de point de vue qui montre ta Droit, non pas seulement comme un organisme de défense, mais sous la forme, plus générale assurément et plus sociale, d'un organisme de rapports salutaires préexistant à toute lésion qui y serait portée (...) il se dégage promptement que cette force doit être étrangère à la sphère privée, et n'appartenir qu'à celle de l'autorité publique. Il faut qu'elle émane du peuple formé en État, à quelque échelon hiérarchique, du reste, que l'autorité executive apparaisse, dès que, déléguée ou non, elle est représentative du total, de l'ensemble. Il s'agit donc de la Force sociale organisée, prête à aller au secours de chacun, peu importe le degré de perfection de cette organisation, civilisée, barbare ou sauvage ; de la force sociale qu'emblématise, trop rudement, le Glaive de la Justice, le Jus gladii" (Cf. Edmond Picard . Le Droit Pur . Paris : Ernest Flammarion, 1908. p. 33). 
Como defensora de uma teoria verdadeiramente concepcionista ${ }^{96}$, Silmara Juny de Abreu Chinellato defende a vida desde a concepção, refutando a tese natalista (que argumentava que seus fundamentos estariam no Direito Romano, o que foi contestado por Pierangelo Catalano), assim como a da personalidade condicional (já exposta e defendida por Clóvis Bevilaqua), sendo o nascituro (assim como - na atualidade - o embrião préimplantatório ${ }^{97}$ ) titular de todos os direitos da personalidade, sem olvidar dos direitos de natureza patrimonial.

\section{O direito geral de personalidade}

Outro ponto relevante para um quadro geral dos direitos da personalidade é estabelecer, quanto ao direito geral de personalidade. De acordo com o relato de Elimar Szaniawski, em sua obra sobre direitos da personalidade, o direito geral de personalidade ressurgiu na Lei Fundamental de Bonn que contemplou no art. $1^{\circ}$ a dignidade do ser humano e, no art. $2^{\circ}$, o direito ao livre desdobramento da personalidade, sendo o ressurgimento atribuído a raízes históricas, uma vez que "os horrores do nazismo, da Segunda Guerra Mundial, e dos regimes totalitários do segundo pós-guerra, que se caracterizaram pelo desprezo pela vida humana e pela personalidade, despertaram os povos para uma nova realidade de proteger, sob todos os aspectos os valores da personalidade e a importância do ser humano como pessoa". 98

96 Ensinou a autora que tal corrente doutrinária seria "denominada concepcionista ou verdadeiramente concepcionista" com o objetivo de "diferenciar-se da teoria da personalidade condicional", uma vez que esta "sustenta que a personalidade começa da concepção e não do nascimento com vida, considerando que muitos dos direitos e 'status'do nascituro não dependem do nascimento com vida, como os direitos da personalidade, o direito de ser adotado, de ser reconhecido, atuando o nascimento sem vida como a morte, para os já nascidos". Prossegue dizendo que "aperfeiçoando mencionada corrente, sustentamos em nossa tese de doutorado e em trabalhos posteriores que a personalidade - que não se confunde com capacidade - não é condicional. Apenas certos efeitos de certos direitos, isto é, os direitos patrimoniais materiais como a herança e a doação, dependem do nascimento com vida. A plenitude da eficácia desses direitos fica resolutivamente condicionada ao nascimento sem vida. O nascimento com vida, enunciado positivo de condição suspensiva, deve ser entendido, ao reverso, como enunciado negativo de uma condição resolutiva, isto é, o nascimento sem vida, porque a segunda parte do artigo $4^{\circ}$ do Código Civil, bem como outros de seus dispositivos, reconhecem direitos (não expectativas de direitos) e estados ao nascituro, não do nascimento com vida, mas desde a concepção" (Cf. Silmara Juny de Abreu Chinelato e Almeida . Direitos da personalidade do nascituro. Revista do Advogado. São Paulo. n. 38, 1992 . p. 22-23).

97 Quanto ao embrião pré-implantatório, assinalou Silmara Juny de Abreu Chinelato e Almeida que " $a$ terminologia jurídica e bioética é bastante imprópria. Descartar, destruir e doar são termos próprios para coisas, sendo incompativeis com a dignidade do embrião pré-implantatório. Mesmo os que não o consideram pessoa, como Ascensión Cambrón Infante e Santos Cifuentes, enfatizam ser necessário tratá-lo com respeito, sem reificá-lo. No mesmo sentido Roberto Andorno, que invoca o princípio 'in dúbio, pro vita', já que não chega a qualificar o embrião pré-implantatório como pessoa, mas, apenas como 'indivíduo da espécie humana' ou 'pessoa virtual' (La distinction juridique entre les personnes et les choses)" (Cf. Silmara Juny de Abreu Chinelato e Almeida . Reprodução humana assistida : aspectos civis e bioéticos . 2000 . Tese (livre-docência em Direito Civil) - Faculdade de Direito, Universidade de São Paulo, São Paulo. p. 167)

98 Cf. Elimar Szaniawski. Direitos da Personalidade e sua Tutela. São Paulo : Revista dos Tribunais, 1993 . p. 56 
Na obra $A$ reconstrução dos Direitos Humanos : um diálogo com o pensamento de Hannah Arendt, em análise mais aprofundada, Celso Lafer destacou o fato de que "num Estado totalitário fundado em princípios criminosos, a lei é instrumento de uma dominação posta a serviço da perversidade, que não se encontra nas pessoas que agem em conjunto ou individualmente, mas sim na dinâmica corruptora do totalitarismo" e "esta dinâmica marcou os algozes, permeou a sociedade e alcançou mesmo as vítimas". 99

A tutela ampla, em consonância com o art. 12 da Convenção da Organização das Nações Unidas sobre Direitos Humanos de $1948^{100}$ e com o art. $8^{\circ}$ da Convenção da Europa, foi reconhecida na Alemanha pela Corte Suprema Federal (BGH) em 1954, sendo admitidos os demais direitos da personalidade com base na Lei Fundamental e no $\S 823$, I do BGB. ${ }^{101}$

O direito geral de personalidade, como enfatizou Antônio Junqueira de Azevedo, é “anterior logicamente, e superior axiologicamente aos vários aspectos da personalidade". ${ }^{102}$

Antonio Junqueira de Azevedo utilizou como referência para suas reflexões os estudos de Rabindranath Valentino Aleixo Capelo de Sousa que, acrescentamos, elaborou obra verdadeiramente paradigmática sobre o tema, na qual definiu o direito geral de personalidade como o direito de cada pessoa "ao respeito e à promoção da globalidade dos elementos, potencialidades e expressões de sua personalidade humana,

99 Cf Celso Lafer . A reconstrução dos Direitos Humanos : um diálogo com o pensamento de Hannah Arendt São Paulo : Companhia das Letras, 1988. p. 178

100 Ao comentar a Declaração Universal dos Direitos Humanos, Amartya Sen constatou que " $a$ nova proclamação refletia uma profunda mudança no pensamento social radical no mundo em transformação no século XX. De fato há um profundo contraste com as proclamações anteriores. Pode-se lembrar que nem mesmo o Presidente Abraham Lincoln tinha, de início, reivindicado direitos sociais e politicos para os escravos - apenas alguns direitos mínimos, referentes à vida, à liberdade e aos frutos do trabalho. A Declaração da ONU abrange sob sua égide uma lista muito maior de pretensões e liberdades. Ela inclui não só direitos políticos básicos, mas também o direito ao trabalho, o direito à educação, a proteção contra o desemprego e a pobreza, o direito de sindicalização e mesmo o direito a uma remuneração justa e favorável. É um avanço radical, muito além dos limites estritos da Declaração americana de 1776 ou da proclamação francesa de 1789". (Cf. Amartya Sen . A ideia de justiça. Tradução de Denise Bottmann e Ricardo Doninelli Mendes. São Paulo: Companhia das Letras, 2011. p. 415)

101 "A Corte Suprema Federal, O BGH expressamente se manifestou a respeito, afirmando que o direito geral de personalidade, extraído dos arts. $1^{\circ}$ e $2^{\circ}$ da Constituição alemã, possui ampla validade e aplicação nas relaçõestípicas de direito privado, reconhecendo-se o direito geral de personalidade como um 'outro direito' no sentido dado pela alínea I do $\S 823$ do BGB, o Código Civil alemão. Essa decisão foi, posteriormente, confirmada por outros arestos, cristalizando-se na jurisprudência o entendimento de que o direito geral de personalidade tutelado pelos mencionados preceitos constitucionais aplicava-se também no âmbito privado. A doutrina alemã, a partir dessas decisões, passou a defender a tese de que o direito geral de personalidade trazido pela Constituição de Bonn tinha sua tutela no próprio Código Civil, no $\S 823$, I sob a rubrica 'outros direitos' (ein sonstiges recht), além dos direitos de personalidade já tipificados naquele dispositivo legal” (Cf. SZANIAWSKI, Elimar. Direitos da personalidade e sua tutela. São Paulo: Revista dos Tribunais, 1993 .p. 58)

102 Cf. Antonio Junqueira de Azevedo. Novos estudos e pareceres de Direito Privado. São Paulo : Saraiva, 2009. p. 485 
bem como da unidade psíquico-físico-sócio-ambiental dessa mesma personalidade humana (v. g. da sua dignidade humana, da sua individualidade concreta e do seu poder de autodeterminação)". ${ }^{103}$

Rabindranath Valentino Aleixo Capelo de Sousa alertou sobre as dificuldades do próprio objeto, ${ }^{104}$ começando pelo conceito de personalidade jurídica, ${ }^{105}$ que não é realmente unívoco. ${ }^{106}$

103 Prosseguiu Rabindranath Valentino Aleixo Capelo de Sousa dizendo que há "a conseqüente obrigação por parte dos demais sujeitos de se absterem de praticar ou de deixar de praticar actos que ilicitamente ofendam ou ameacem ofender tais bens jurídicos da personalidade alheia, sem o que incorrerão em responsabilidade civil elou na sujeição às providências civeis adequadas a evitar a consumação da ameaça ou a atenuar os efeitos da ofensa cometida" (Cf. Rabindranath Valentino Aleixo Capelo de Sousa . O direito geral de personalidade. Coimbra: Coimbra, 1995. p. 93)

$104 \mathrm{Na}$ Alemanha, houve certa inércia quanto à reformulação de alguns dos dispositivos do BGB ( $\$ \S 823$, 825), o que demonstrou - de certa forma - que o legislador não teve o mesmo ímpeto renovador que os doutrinadores e que a jurisprudência, sendo desta a principal contribuição para a construção do direito geral da personalidade, como assinalou Alessandro Somma: "Il diritto generale della personalità è dunque um istituto di creazione giusrisprudenziale che è oramai uma realtà dai contorni sostanzialmente definiti. Poço importa quindi che nella Germania del dopoguerra esso sai sorto - e si sia quindi sviluppato - forse più per reazione ad un passato ostile al riconoscimento dei diritti umani, che per volontà di prescindere dalle indicazioni del legislatore. Quest'ultimo ha del resto tentato in più riprese e senza successo di procurare un fondamento positivo - peraltro nel sostanziale rispetto delle linee guida tracciate dai giudici - alla disciplina che si è illustrata" (Cf. Alessandro Somma . I diritti della personalità e il diritto generale della personalità nell'ordinamento privatistico della Repubblica Federale Tedesca. Rivista Trimestrale di Diritto e Procedura Civile. Milão . v. 50. n.3 . set.1996. p. 834)

105 Apesar das dificuldades em sua conceituação, Adriano De Cupis ponderou, quanto à personalidade jurídica, que "poichè quel fine e quella libertà sono dati all'uomo come tale, la personalità dell'uomo stesso costituisce un suo valore naturale, indipendente dalla vita sociale e dal correlativo ordine giuridico. La personalità giuridica è la traduzione in termini giuridici di tale valore, mediante l'attribuzione di una posizione giuridica congrua rispetto a questo stesso valore, di una posizione, cioè, per cui l'essere umano può introdursi come principio attivo nei rapporti dell'ordine giuridico. In questa posizione giuridica, che è posizione dell'uomo di fronte agli altri uomini, si riflette la naturale dignità dell'uomo stesso" (Cf. Adriano De Cupis . I diritti della personalità . t. I . Milão : Giuffrè, 1959 . p. 23). Cabe ainda acrescentar, quanto a tal questão que a afirmação de Rabindranath Valentino Aleixo Capelo de Sousa é procedente, mas que adotaremos aqui um conceito mais simples, proposto por José Carlos Moreira Alves e fundado nas lições de Barbero, no qual "personalidade jurídica é a aptidão de adquirir direitos e de contrair obrigações", ponderando que "em geral, os autores consideram sinônimas as expressões personalidade jurídica e capacidade jurídica", mas "enquanto personalidade jurídica é conceito absoluto (ela existe, ou não existe), capacidade jurídica é conceito relativo (pode ter-se mais capacidade jurídica, ou menos). A personalidade jurídica é o limite dessa potencialidade" (Cf. José Carlos Moreira Alves . Direito Romano . 14 a ed. . Rio de Janeiro : Forense, 2007. p. 103)

106 Como acentuou Rabindranath Valentino Aleixo Capelo de Sousa, se "de um ponto de vista formal, curase aqui fundamentalmente de saber qual o sentido e alcance da tutela geral da personalidade prevista no art. $70^{\circ}$ do Código Civil português, qual o âmbito do seu objecto, quais as pessoas que entrelaça, quais os modos e os termos dessa tutela, qual a sua articulação e delimitação face a figuras jurídicas que lhe são próximas ou afins e trata-se, finalmente, de nos interrogarmos sobre se de tal tutela emerge um direito geral de personalidade e qual será, então, a sua natureza jurídica", pois "surgem imediatas dificuldades gnoseológicas na determinação apriorística do objecto material do nosso estudo. Com efeito, no centro e no curso da problemática da tutela juscivilística da personalidade, determinando-a e irreflectindo-a, está o Homem ou, porventura mais do que isso, cada homem concreto com a própria e dinâmica personalidade, confluindo aí, e muitas vezes antinomicamente, desígnios de ordenação social, veiculados através da estrutura jurídica. Jurisgenesicamente, poderíamos ser tentados a buscar refúgio na ideia de personalidade 
A questão é realmente saber se o ordenamento jurídico brasileiro adotou ou não redação semelhante - no art. 12 do Código Civil - à que existe no art. 70 do Código Civil português, no qual restou inequívoca tal opção ${ }^{107}$, ainda que - mesmo neste - seja essencial a atuação jurisprudencial em razão de um grau acentuado de vaguidade que decorre da própria natureza da matéria, como acentuou Antonio Menezes Cordeiro ${ }^{108}$.

Textos legais que consagraram o direito geral de personalidade, como o já citado diploma legal português e o Código Civil de Macau (no artigo 67 ${ }^{109}$ ), enfrentaram dificuldades decorrentes da própria inexistência de unidade em torno do conceito.

Em alentado estudo sobre os direitos da personalidade no Código Civil de Macau, Paulo Cardoso Correia da Mota Pinto considerou que "ao consagrar o direito geral de personalidade, o legislador do Código Civil de Macau revelou, além de atenção ao sentido de desenvolvimentos dogmáticos noutras ordens jurídicas, uma preocupação personalista que é de louvar", e que não existe a já mencionada unidade (em especial entre os juristas germânicos) "em torno da concepção do direito geral de personalidade" e que "na realidade, a simples consagração de um direito geral de personalidade não resolve de uma penada os complexos problemas de aplicação e delimitação práticas que este suscita" 110 .

jurídica como elemento fundante e explicativo da tutela geral de personalidade. Porém, não é unívoco o conceito de personalidade, mesmo para efeitos tão só jurídicos". (Cf. Rabindranath Valentino Aleixo Capelo de Sousa. $O$ direito geral de personalidade. Coimbra: Coimbra, 1995 . p. 13).

107 Artigo $70^{\circ}$ (tutela geral da personalidade) 1. A lei protege os individuos contra qualquer ofensa ilicita ou ameaça de ofensa à sua personalidade física ou moral. 2. Independentemente da responsabilidade civil a que haja lugar, a pessoa ameaçada ou ofendida pode requerer as providências adequadas às circunstâncias do caso, com o fim de evitar a consumação da ameaça ou atenuar os efeitos da ofensa já cometida.

108 Na lição de Antonio Menezes Cordeiro “a jurisprudência tem, no domínio do Direito da Personalidade, um papel fundamental. Os textos legais relativos à tutela da pessoa têm, pela própria natureza da matéria em jogo, um grau acentuado de vaguidade. O art. $70^{\circ} / 1$, ao referir protecção contra qualquer ofensa ilícita ou ameaça de ofensa à personalidade física ou moral lida com conceitos indeterminados: 'personalidade física' e 'personalidade moral'. Tentar uma concretização com base nas idéias de 'integridade', de 'vida', de 'honra, de 'reputação', de 'sossego' ou similares apenas permite pequenos avanços. No fundo, trata-se de esclarecer: a que situações da vida se aplicam os dispositivos relativos a direitos da personalidade $e$ com que conseqüências. A recolha dos casos concretos é indispensável" (Cf. António Menezes Cordeiro . Os direitos de personalidade na civilística portuguesa. Revista da Ordem dos Advogados . Lisboa. v. 61 . n.3 . 2001 . p. 1245)

109 Artigo 67. ${ }^{\circ}$ (Tutela geral da personalidade) 1. Os direitos de personalidade são reconhecidos a todas as pessoas e devem ser protegidos sem qualquer discriminação injustificada, nomeadamente por motivos de nacionalidade, local de residência, ascendência, raça, etnia, cor, sexo, língua, religião, opinião ou convicção política ou ideológica, instrução e situação económica ou condição social. 2. Todas as pessoas têm direito à protecção contra qualquer ofensa ilícita ou ameaça de ofensa à sua personalidade física ou moral. 3. Independentemente da responsabilidade civil a que haja lugar, a pessoa ameaçada ou ofendida pode requerer as providências adequadas às circunstâncias do caso, com o fim de evitar a consumação da ameaça ou atenuar os efeitos da ofensa já cometida. 4. As medidas referidas no número anterior poderão também ser requeridas como providências cautelares, nos termos da lei de processo.

$110 \mathrm{O}$ autor complementou seu raciocínio dizendo que "designadamente, o direito geral de personalidade carece de uma delimitação clara, tendo os seus limites que ser precisados, desde logo porque a protecção de uma pessoa pode contender com o livre desenvolvimento (e a personalidade) da outra" (Cf. Paulo Cardoso 
Jorge Miranda, Otávio Luiz Rodrigues Júnior e Gustavo Bonato Fruet, após relatarem que a existência de um direito geral da personalidade é defendida em razão dos diversos tipos de lesões aos direitos da personalidade, informam a existência de um embate em Portugal quanto à sua aceitação, sendo a Escola de Direito de Coimbra favorável e a de Lisboa majoritariamente contrária. ${ }^{111}$

Há a percepção, entre os críticos, de que "a necessidade de criação de um direito geral na Alemanha decorreu das lacunas de legislação civil sobre o tema, o que levou a jurisprudência a extrair o direito geral da Grundgesetz e formulá-lo em termos judiciais" e que "a existência de direitos da personalidade em espécie, como se dá em Portugal e também no Brasil, dispensaria esse recurso técnico". ${ }^{112}$

No Brasil, como já salientamos, discute-se igualmente a respeito da consagração do direito geral de personalidade no art. 12 do Código Civil. Todavia, advertiu Silmara Juny de Abreu Chinellato que o dispositivo simplesmente revela uma enumeração não exaustiva de direitos, ${ }^{113}$ não existindo no dispositivo o direito geral de personalidade tão discutido em outros sistemas.

Correia da Mota Pinto . Os direitos de personalidade no Código Civil de Macau . Boletim da Faculdade de Direito da Universidade de Coimbra . Coimbra . v. 76. p. 205-50, 2000 . p. 218).

111 “As críticas são divididas em dois grupos: (a) haveria impossibilidade lógica de um sujeito de direito ser objeto da situação jurídica por ele titularizada; (b) o direito da personalidade é categoria desnecessária, com amplitude exagerada e que pode resultar em abusos, especialmente quando se tem à mão a ideia de que esses direitos subordinam-se ao regime de numerus apertus. Chega-se à fórmula de que esse é um direito 'concebível, porém, dispensável”' (Cf. Jorge Miranda, Otávio Luiz Rodrigues Júnior e Gustavo Bonato Fruet . Principais problemas dos direitos da personalidade e estado-da-arte da matéria no Direito comparado . Direitos da personalidade. Jorge Miranda, Otávio Luiz Rodrigues Júnior e Gustavo Bonato Fruet (orgs. ). São Paulo: Atlas, 2012 . p. 18)

112 Cf. Jorge Miranda, Otávio Luiz Rodrigues Júnior e Gustavo Bonato Fruet . op. cit. . p. 18

113 Asseverou Silmara Juny Chinellato, em seus comentários ao artigo 12 do Código Civil, que "o artigo trata da tutela geral dos direitos da personalidade, inclusive no âmbito preventivo, podendo o lesado socorrer-se das medidas processuais cabiveis: medida cautelar nominada e inominada, tutela antecipada, mandado de segurança com pedido de liminar, considerando-se a qualidade do lesante), para a ameaça de direitos, bem como ação constitutiva ou declaratória para a lesão consumada" e, quanto ao ponto em análise que "há quem sustente que o artigo consagrou o direito geral de personalidade, parecendo-me, no entanto, que a opção do legislador foi pela enumeração não exaustiva dos direitos. Anoto que a não taxatividade é mais uma das características dos direitos da personalidade. Além da tutela geral, há sanções especificas previstas em leis especiais, como a Lei de Direitos Autorais (arts. 102 a 110 da Lei n. 9.610, de 19.02.1998)" (Cf. Silmara Juny de Abreu Chinellato . Comentários à Parte Geral - artigos $1^{\circ}$ a 21 do Código Civil. In: Antonio Cláudio da Costa Machado. (Org.) Silmara Juny Chinellato (Coord.) . Código Civil Interpretado : artigo por artigo, parágrafo por parágrafo. $5^{\mathrm{a}}$ ed. . Barueri : Manole, 2012 .p. 43 ) 


\section{Conclusão}

Finalizando, em nossa visão, calcada nos ensinamentos dos muitos juristas aqui $\operatorname{citados}^{114}$, descabe igualmente pretender - de forma inócua - encontrar uma disposição normativa mais ampla do que as já existentes em nosso ordenamento jurídico e $\mathrm{o}$ art. $1^{\circ}$, III da Constituição Federal consagra o indispensável reconhecimento à dignidade da pessoa humana, sem a qual inexiste uma ordem jurídica efetivamente justa e sempre com a relevância e adequação que estão na gênese de tal dispositivo.

Para tanto, destacamos que outro esforço deve ser feito no sentido de evitar que ocorra qualquer distorção ou mesmo uma banalização dos direitos da personalidade ou que seja igualmente ameaçado o seu próprio fundamento - a "dignidade da pessoa humana" - na medida em que esta é diuturnamente invocada fora de seu contexto e citada para justificar questões totalmente distintas em projetos de lei, julgados, monografias, dissertações e teses, sem olvidar de seu uso constante em petições como uma vazia peça de retórica.

São Paulo, dezembro de 2012.

\section{Referências}

\section{Livros}

ALVES, José Carlos Moreira . A parte geral do projeto de código civil brasileiro: subsídios históricos para o novo Código Civil brasileiro. 2. ed. São Paulo: Saraiva, 2003.

Direito romano. 14. ed. Rio de Janeiro : Forense, 2007.

AMARAL, Francisco. Direito civil: introdução. 7. ed. Rio de Janeiro: Renovar, 2008.

AZEVEDO, Álvaro Villaça . Prisão civil por dívida. 2. ed. São Paulo: Revista dos Tribunais, 2000.

AZEVEDO, Antonio Junqueira de. Novos estudos e pareceres de direito privado. São Paulo: Saraiva, 2009.

BEVILAQUA, Clóvis. Theoria geral do direito civil. 2. ed. Rio de Janeiro: Francisco Alves, 1929.

114 A todos o nosso agradecimento, em especial porque tivemos a rara oportunidade de cursar disciplinas e receber valiosas lições (que vão além das que estão à disposição nos livros) durante o mestrado e o doutorado (1995 a 2004) de juristas do porte de Rubens Limongi França, Carlos Alberto Bittar, Silmara Juny de Abreu Chinellato, Antônio Junqueira de Azevedo, Fábio Maria De Mattia, Álvaro Villaça Azevedo, Rui Geraldo Camargo Viana e Daisy Gogliano (e isso mencionando apenas alguns dos que se dedicaram à pesquisa dos direitos da personalidade no Departamento de Direito Civil da Faculdade de Direito da Universidade de São Paulo) 
BITTAR, Carlos Alberto. Os direitos da personalidade. Rio de Janeiro: Forense Universitária, 1989. BOBBIO, Norberto. A era dos direitos. Tradução de Carlos Nelson Coutinho. 9. ed. Rio de Janeiro: Elsevier, 2004.

BONAVIDES, Paulo. Curso de direito constitucional. 19. ed. São Paulo: Malheiros, 2006.

BORGES, Roxana Cardoso Brasileiro. Disponibilidade dos direitos de personalidade e autonomia privada. São Paulo: Saraiva, 2005.

CALDAS, Pedro Frederico. Vida privada, liberdade de imprensa e dano moral. São Paulo : Saraiva, 1997.

CANOTILHO, José Joaquim Gomes. Direito constitucional. 6. ed. Coimbra: Almedina, 2002.

CHAVES, Antônio. Direito à vida e ao próprio corpo: intersexualidade, transexualidade, transplantes. 2. ed. São Paulo : Revista dos Tribunais, 1994.

. Lições de direito civil: parte geral 3. São Paulo: Bushatsky - Edusp, 1972.

ALMEIDA, Silmara Juny de Abreu Chinelato e. Tutela civil do nascituro. São Paulo: Saraiva, 2000.

COMPARATO, Fábio Konder . A afirmação histórica dos direitos humanos. São Paulo: Saraiva, 1999.

CORDEIRO, António Menezes. Tratado de direito civil português: direito das obrigações. Coimbra: Almedina, 2010. v. II . t. III

COSTA JÚNIOR, Paulo José da . O direito de estar só: tutela penal da intimidade. 4. ed. São Paulo: Revista dos Tribunais, 2007

DE CUPIS, Adriano. I diritti della personalità. Milão: Giuffrè, 1959. t. 1.

FERREIRA FILHO, Manoel Gonçalves. Direitos humanos fundamentais. São Paulo : Saraiva, 1996.

FRANÇA, Rubens Limongi. Do nome civil das pessoas naturais. São Paulo: Revista dos Tribunais, 1958.

. Manual de direito civil. 2. ed. São Paulo: Revista dos Tribunais, 1971. v. 1.

GODOY, Cláudio Luiz Bueno de. A liberdade de imprensa e os direitos da personalidade. 2. ed. São Paulo: Atlas, 2008.

GOMES, Joaquim B. Barbosa. Ação afirmativa \& princípio constitucional da igualdade: o direito como instrumento de transformação social: a experiência dos EUA . Rio de Janeiro: Renovar, 2001.

GOMES, Orlando. Introdução ao direito civil. 14. ed. atual. e notas de Humberto Theodoro Júnior. Rio de Janeiro: Forense, 1999.

. Raizes históricas e sociológicas do Código Civil brasileiro. 2. ed. São Paulo: Martins Fontes, 2006. 
JABUR, Gilberto Haddad. Liberdade de pensamento e direito à vida privada: conflitos entre direitos da personalidade. São Paulo: Revista dos Tribunais, 2000.

LAFER, Celso. A reconstrução dos direitos humanos: um diálogo com o pensamento de Hannah Arendt. São Paulo: Companhia das Letras, 1988.

LORENZETTI, Ricardo Luis. Fundamentos do direito privado. Tradução de Vera Maria Jacob de Fradera . São Paulo: Revista dos Tribunais, 1998.

LOTUFO, Renan. Código civil comentado: parte geral (arts. $1^{\circ}$ a 232). São Paulo: Saraiva, 2003. v. 1.

MAZZUOLI, Valério de Oliveira. Prisão civil por dívida e o Pacto de San José da Costa Rica: de acordo com o novo código civil brasileiro (Lei n. 10.406/2002) . Rio de Janeiro: Forense, 2002.

MIRANDA, Jorge . Teoria do estado e da constituição. Rio de Janeiro: Forense, 2002.

MORATO, Antonio Carlos. Direito de autor em obra coletiva. São Paulo: Saraiva, 2007. . Pessoa jurídica consumidora. São Paulo: Revista dos Tribunais, 2008.

PEREIRA, Caio Mário da Silva. Direito civil: alguns aspectos de sua evolução. Rio de Janeiro: Forense, 2001.

PICARD, Edmond. Le droit pur. Paris: Ernest Flammarion, 1908.

PIOVESAN, Flávia. Direitos humanos e o direito constitucional internacional. São Paulo: Max Limonad, 1996.

MIRANDA, Francisco Cavalcanti Pontes de. Tratado de direito privado. Rio de Janeiro: Borsoi, 1955. t. 7.

REALE, Miguel. História do novo Código Civil. São Paulo: Revista dos Tribunais, 2005.

ROUSSEAU, Jean-Jacques. Du contrat social ou principes du Droit politique. Oeuvres complètes . t. III . Bibliothèque de La Pléiade, Paris: Gallimard, 1964.

SAHM, Regina. Direito à imagem no Direito Civil contemporâneo: de acordo com o novo Código Civil - Lei n. 10.406, de 10-1-2002. São Paulo: Atlas, 2002.

SCHUBSKY, Cássio. Clóvis Beviláqua: um senhor brasileiro. São Paulo: Lettera.doc, 2010.

SEN, Amartya. A ideia de justiça. Tradução de Denise Bottmann e Ricardo Doninelli Mendes. São Paulo: Companhia das Letras, 2011.

SOUSA, Rabindranath Valentino Aleixo Capelo de. O direito geral de personalidade. Coimbra: Coimbra, 1995.

SZANIAWSKI, Elimar. Direitos da Personalidade e sua Tutela. São Paulo: Revista dos Tribunais , 1993

TELLES JÚNIOR, Goffredo. Iniciação na ciência do direito. São Paulo: Saraiva, 2001. 
TOBEÑAS, Jose Castan. Los derechos de la personalidad. Madri: Instituto Editorial Reus, 1952.

VINEY, Geneviève. Traité de droit civil: les obligations: la responsabilité: effects. Paris: L.G.D.J., 1988.

ZANINI, Leonardo Estevam de Assis. Direitos da personalidade: aspectos essenciais. São Paulo: Saraiva, 2011.

\section{Capítulos de livros}

CHINELLATO, Silmara Juny de Abreu. Comentários à parte geral - artigos $1^{\circ}$ a 21 do Código Civil. In: MACHADO, Antonio Cláudio da Costa. (Org.). CHINELLATO, Silmara Juny (Coord.). Código civil interpretado: artigo por artigo, parágrafo por parágrafo. 5. ed. Barueri: Manole, 2012. p. 30-51.

DE MATTIA, Fábio Maria. Direitos da personalidade: aspectos gerais. Estudos de Direito Civil . Antônio Chaves (Coord.). São Paulo: Revista dos Tribunais, 1979. p. 99-124.

MARTINS, Leonardo. Introdução à jurisprudência do Tribunal Constitucional Federal Alemão. Cinqüenta anos de jurisprudência do Tribunal Constitucional Federal Alemão. Organização e introdução: Leonardo Martins; Trad. Beatriz Henning et al. . Prefácio: Jan Woischnik .Coletânea Original de Jürgen Schwabe. Montevidéu: Fundação Konrad Adenauer, 2005. p. 33-126.

MIRANDA, Jorge; RODRIGUES JUNIOR, Otavio Luiz; FRUET, Gustavo Bonato. Principais problemas dos direitos da personalidade e estado-da-arte da matéria no Direito comparado . Direitos da personalidade. Jorge Miranda, Otávio Luiz Rodrigues Júnior e Gustavo Bonato Fruet (Org.). São Paulo: Atlas, 2012. p. 1-23.

MORAES, Walter. Direitos da personalidade: estado da matéria no Brasil. In: CHAVES, Antônio (Coord.). Estudos de direito civil. São Paulo: Revista dos Tribunais, 1979. p. 125-138.

\section{Artigos}

ALMEIDA, Silmara Juny de Abreu Chinelato e. Direitos da personalidade do nascituro. Revista do Advogado, São Paulo, n. 38, p. 21-30, 1992.

CORDEIRO, António Menezes. Os direitos de personalidade na civilística portuguesa. Revista da Ordem dos Advogados, Lisboa, v. 61, n. 3, p. 1229-56, 2001.

FRANÇA, Rubens Limongi. Direitos da personalidade coordenadas fundamentais. Revista do Advogado, São Paulo, n. 38, p. 5-13, dez. 1992.

PINTO, Paulo Cardoso Correia da Mota. Os direitos de personalidade no Código Civil de Macau. Boletim da Faculdade de Direito da Universidade de Coimbra, Coimbra, v. 76, p. 205-50, 2000. 
SOMMA, Alessandro. I diritti della personalità e il diritto generale della personalità nell'ordinamento privatistico della Repubblica Federale Tedesca. Rivista Trimestrale di Diritto e Procedura Civile, Milão, v. 50, n. 3, p. 807-35, 1996.

\section{Teses e Dissertações}

ALMEIDA, Silmara Juny de Abreu Chinelato e. Reprodução humana assistida: aspectos civis e bioéticos. 2000. Tese (Livre-docência) - Faculdade de Direito, Universidade de São Paulo, São Paulo.

GOGLIANO, Daisy. Direitos privados da personalidade. 1982 . Dissertação (Mestrado) - Faculdade de Direito, Universidade de São Paulo, São Paulo.

PRUDENTE, Eunice Aparecida de Jesus. Direito à personalidade integral: cidadania plena. 1996. Tese (Doutorado) - Faculdade de Direito, Universidade de São Paulo, São Paulo.

\section{Aulas e Palestras}

BITTAR, Carlos Alberto. Ambito da teoria dos direitos da personalidade. Aula ministrada no curso “Teoria Geral do Direito Civil: Direitos da Personalidade”. Pós-graduação da Faculdade de Direito da Universidade de São Paulo (USP), São Paulo, 21 mar. 1995.

\section{Documento jurídico}

BRASIL. Assembléia Nacional Constituinte de 1988 . Atas das Comissões. Diário da Assembléia Nacional Constituinte de 1988. Direitos e garantias individuais, em Quinta Reunião de Audiência Pública realizada em 29 de abril de 1987. Brasília: Congresso Nacional, Ano I, p. 94.

\section{Textos em meio eletrônico}

Cançado Trindade Questiona a Tese de "Gerações de Direitos Humanos" de Norberto Bobbio. DHNet - Direitos Humanos na Internet. Disponível em: <http://www.dhnet.org.br/direitos/ militantes/cancadotrindade/cancado_bob.htm>. Acesso em: 15 set. 2007. 